\title{
THE ELUSIVE RIGHT TO TRUTH IN TRANSITIONAL HUMAN RIGHTS JURISPRUDENCE
}

\author{
JAMES A SWEENEY*
}

\begin{abstract}
This article undertakes a comparative legal analysis of the scope of an emerging legal duty to find the truth about historical human rights abuses after periods of political transition. There is substantial inconsistency between human rights regimes on how they establish temporal jurisdiction in their transitional jurisprudence, which has not yet been systematically investigated. This contribution fills the gap in the literature by identifying and critiquing the way in which the right to truth in times of transition is both expressly and implicitly vindicated in the decisions of the Human Rights Committee, and the regional jurisprudence of the Inter-American Court of Human Rights and European Court of Human Rights (the conclusion also addresses the less voluminous African regional jurisprudence). It is argued that the 'underlying values' of human rights treaties can provide a foundation for a powerful but finite right to truth.
\end{abstract}

Keywords: admissibility ratione temporis, African Court of Human and People's Rights, European Court of Human Rights, human rights, Human Rights Committee, Inter-American Court of Human Rights, right to truth, transitional justice.

\section{INTRODUCTION}

This article undertakes a comparative legal analysis of the 'right to truth' in international human rights jurisprudence, with a particular focus on the underexplored but crucial question of the scope of an emerging legal duty to find the truth about historical human rights abuses in periods of political transition.

The search for the truth about the past is particularly significant in 'transitional' societies - those transitioning from conflict to peace, from totalitarianism to democracy. The UN Secretary General has stressed the importance of truth within the framework of transitional justice, ${ }^{1}$ and the

* Professor of International Law, Centre for International Law and Human Rights, Lancaster University Law School (UK) j.sweeney@lancaster.ac.uk. The research underpinning this piece was first presented at a workshop arranged by The Center for Global Public Law and PluriCourts, University of Oslo, and held at Koç University, Istanbul, in September 2015. Thanks to the organisers and participants, in particular to Bașak Çalı, for their insights. Later versions of this piece benefited from discussions with Kieran McÉvoy, Steven Wheatley, and Alice Panepinto. Many thanks also to the anonymous reviewers at ICLQ.

1 Report of the Secretary General on the Rule of Law and Transitional Justice in Conflict and Post-Conflict Situations (2004) UN Doc S/2004/616, 4, 17. 
significance of 'historical justice' is well-recognized in the transitional justice literature. ${ }^{2}$ Ruti Teitel, for example, observed that transitional history making is endowed with, 'real transformative potential'. ${ }^{3}$ The Inter-American Commission on Human Rights has stated that, 'reaching at a complete, factual and impartial truth - reconstructed, shared and legitimized by society - is a fundamental factor in restoring citizens' confidence in the institutions of the State'. ${ }^{4}$

Yet, although the importance of knowing the truth about human rights violations of the past is widely recognized, this can be distinguished from the emergence of a legal 'right' to truth per se. ${ }^{5}$ Indeed the first part of this article demonstrates that an international legal 'right to truth' remains elusive. ${ }^{6}$ In the narrower realm of international human rights jurisprudence, ${ }^{7}$ however, there have been tangible developments. These developments intersect with emerging standards on countering impunity and the promotion of victims' rights to a remedy for gross and systematic human rights violationsalthough it is readily conceded that truth-finding via criminal prosecution and public judicial record is far from the only means of achieving historical justice. ${ }^{8}$

We shall see that the right to truth in international human rights law is closely connected ${ }^{9}$ to the duties to investigate or to prosecute, identified for example in the pioneering work of Naomi Roht-Arriaza, ${ }^{10}$ Diane Orentlicher ${ }^{11}$ and Juan Méndez, ${ }^{12}$ (and later enshrined in the various soft-law instruments discussed below). However, there are distinct challenges to imposing the duty to investigate and prosecute on successor regimes, and therefore to using such

2 R Teitel, Transitional Justice (Oxford University Press 2000).

3 ibid, 71. 2014).

4 Inter-American Commission on Human Rights, The Right to Truth in the Americas (ACmHR 175.

See D Groome, 'The Right to Truth in the Fight against Impunity' (2011) 29 BerkJIntlL 175,

${ }^{6}$ For example contrast the more tempered conclusion of Y Naqvi, 'The Right to the Truth in International Law: Fact or Fiction?' (2006) 88 IRRC 245 (discussed further below) with S SzokeBurke, 'Searching for the Right to Truth: The Impact of International Human Rights Law on National Transitional Justice Policies' (2015) 33 BerkJIntlL 526, who found that the right to truth is, 'a legally binding (lex lata) norm'.

7 The term 'jurisprudence' here, and throughout, refers to the judicial and quasi-judicial findings of international human rights enforcement bodies in contentious proceedings. In addition to the findings of the European, Inter-American and African Courts of Human (and Peoples') Rights this includes, therefore, the 'Views' of the Human Rights Committee of the ICCPR. We shall also more briefly note relevant jurisprudence of the Inter-American and African Commissions on Human (and Peoples') Rights.

8 Teitel (n 2) 72, noting the varied sources and forms of 'transitional truths'; See also M LawryWhite, 'The Reparative Effect of Truth Seeking in Transitional Justice' (2015) 64 ICLQ 141, arguing for an 'holistic' approach to transitional justice and truth seeking rather than relying upon a single method (such as prosecutions alone, especially where for institutional or political reasons only a small number of alleged perpetrators could be tried).

9 See Szoke-Burke (n 6) 532.

10 N Roht-Arriaza, 'State Responsibility to Investigate and Prosecute Grave Human Rights Violations in International Law' (1990) 78 CLR 449.

11 D Orentlicher, 'Settling Accounts: The Duty to Prosecute Human Rights Violations of a Prior Regime' (1991) 100 YaleLJ 2537.

12 J Méndez, 'Accountability for Past Abuses' (1997) HRtsQ 255. 
duties to gain access to the truth about pre-transition human rights abuses. These challenges arise from limits upon the temporal jurisdiction of international human rights courts. ${ }^{13}$

When States only ratify human rights treaties ${ }^{14}$ after the restoration of peace or democracy, complaints regarding pre-transition human rights abuses will ordinarily be inadmissible ratione temporis. This is rooted in the general principle of the non-retroactivity of treaties, ${ }^{15}$ and the way in which human rights courts and tribunals established by treaty have adjudicated upon disputes about their temporal jurisdiction. ${ }^{16}$ Both are connected to the extent of each State party's consent to be bound by the treaty in question.

In the jurisprudence, the date upon which the relevant human rights treaty or its enforcement mechanism becomes effective for a particular State party is often referred to as the 'crucial' or 'critical' date. ${ }^{17}$ The substantial inconsistency between human rights regimes on the extent to which their enforcement bodies have temporal jurisdiction over human rights violations rooted in events before the 'crucial date' has not yet been systematically investigated. ${ }^{18}$ It is shown here that despite the close association between

13 This is not only a problem for the right to truth. There have been similar concerns about the inability of human rights courts to require the restitution of property taken prior to ratification of the relevant human rights treaty. See T Allen, 'Restitution and Transitional Justice in the European Court of Human Rights' (2007) 13 ColumJEurL 1; A Buyse, Post-Conflict Housing Restitution (Intersentia 2008); and JA Sweeney, 'Law and Policy on Post-Conflict Restitution' in M Saul and JA Sweeney (eds), International Law and Post-Conflict Reconstruction Policy (Routledge 2015).

${ }^{14}$ Or accept the contentious jurisdiction of the relevant enforcement body, if such acceptance is a step additional to ratification.

15 See art 28 Vienna Convention on the Law of Treaties (adopted 23 May 1969, entered into force 27 January 1980) 1155 UNTS 331.

16 See A Koroma, 'Assertion of Jurisdiction by the International Court of Justice' in P Capps et al. (eds), Asserting Jurisdiction: International and European Legal Perspectives (Hart 2003) 196, noting, in relation to the International Court of Justice, that where its jurisdiction derives from a treaty, the potential retroactivity of the Court's jurisdiction is separate to retroactivity of the obligations arising out of the treaty itself.

${ }_{17}$ See Silih v Slovenia (App No 71463/01) (2009) 49 EHRR 996, para 140, discussed in depth below.

${ }^{18}$ Roht-Arriaza discussed, 'the problem of successor governments' but did not directly address the issue of admissibility ratione temporis in human rights law: Roht-Arriaza (n 10) 432; likewise Orentlicher's analysis (n 11) of prosecutory duties in respect of a 'prior regime' did not examine admissibility ratione temporis; and whilst Mendez found that the State's obligation, 'to disclose to the victims, their families, and society all that can be reliably established about [crimes against humanity]' was correlative to, 'a right to know the truth' (Mendez (n 12) 261), he also did not examine the temporal problem in respect of many 'past abuses'. Eva Brems did examine it briefly in her analysis of the European Court of Human Rights' transitional jurisprudence: E Brems, 'Transitional Justice in the Case Law of the European Court of Human Rights' (2010) 5 IJTJ 282, 287-but without linking the duty to investigate to the emerging right to truth. Of studies of the right to truth per se, none of Groome (n 5), Naqvi (n 6), Szoke-Burke (n 6) nor, more recently, Panepinto examined the temporal issue, although Panepinto alluded to obligations upon 'successor regimes' to investigate 'historic abuses': A Panepinto, 'The Right to the Truth in International Law: The Significance of Strasbourg's Contributions' (2017) Legal Studies (Early View, available at <http://onlinelibrary.wiley.com/doi/10.1111/lest.12172/full >. Pinpoint references to this piece will refer to the Early View pdf. 
truth-seeking and transitional justice, the capacity of international human rights law to vindicate the right to truth in respect of even notorious events before the 'crucial date' is worryingly uncertain.

This article examines the way in which the right to truth is both explicitly and implicitly vindicated in the global jurisprudence of the ICCPR Human Rights Committee, ${ }^{19}$ and the regional jurisprudence of the Inter-American Court of Human Rights ${ }^{20}$ and European Court of Human Rights ${ }^{21}$ (the conclusion also addresses the less voluminous African regional jurisprudence). ${ }^{22}$ The general approach to the right to truth in each human rights regime is identified and analysed, followed by critical discussion of each regime's 'transitional jurisprudence' ${ }^{23}$ on the admissibility ratione temporis of complaints seeking the truth about events before the 'crucial date'. The conclusion proposes a cohesive approach to the right to truth in transitional jurisprudence, rooted in the 'underlying values' of each human rights treaty. Thus, this piece is intended to make a contribution both to the vindication of victims' and their next of kins' rights to know about pre-transition human rights abuses, as well as to the developing literature on the transitional jurisprudence of human rights enforcement bodies.

\section{THE ELUSIVENESS OF THE RIGHT TO TRUTH IN INTERNATIONAL LAW}

This section identifies that whilst there is a plethora of references to the right to truth in international soft law, its status as a legal right in public international law is moot.

The UN's Set of Principles for the Protection and Promotion of Human Rights through Action to Combat Impunity devote considerable attention to 'The right to know' and refer to the right to truth as being 'imprescriptible'. ${ }^{24}$ Likewise the Basic Principles and Guidelines on the Right to a Remedy and Reparation for

19 Established by the International Covenant on Civil and Political Rights (adopted 16 December 1966, entered into force 23 March 1976) 999 UNTS 171, and empowered to receive individual communications by the Optional Protocol to the International Covenant on Civil and Political Rights (adopted 16 December 1966, entered into force 23 March 1976).

20 Established by the American Convention on Human Rights (adopted 21 November 1969, entered into force 18 July 1978) 1144 UNTS 123 (ACHR). The focus of this piece is upon the enforcement regime established by the ACHR. For members of the Organisation of American States that have not ratified the ACHR, a separate regime based upon the 1948 American Declaration and monitored by the Inter-American Commission applies: see American Declaration of the Rights and Duties of Man (1949) 43 AJIL Supp 133.

21 Established by the Convention for the Protection of Human Rights and Fundamental Freedoms (European Convention on Human Rights), as amended.

${ }^{22}$ The focus is upon identifying and analysing jurisprudence that is 'functionally equivalent' in its potential to vindicate the right to truth, rather than on comparing the jurisprudence on formally equivalent treaty provisions. On functionality see $\mathrm{K}$ Zweigert and $\mathrm{H}$ Kötz, An Introduction to Comparative Law (3rd edn, Oxford University Press 1998) 34.

${ }^{23}$ The term 'transitional jurisprudence' is used here to describe the jurisprudence of human rights enforcement bodies relating to societies in transition. See eg A Buyse and M Hamilton (eds), Transitional Jurisprudence and the ECHR (Cambridge University Press 2011).

24 UNCHR, 'Updated Set of Principles for the Protection and Promotion of Human Rights through Action to Combat Impunity', UN Doc E/CN.4/2005/102. 
Victims of Gross Violations of International Human Rights Law and Serious Violations of International Humanitarian $\mathrm{Law}^{25}$ state that victims and their representatives should be able to 'learn the truth' about gross violations of international human rights law and serious violations of international humanitarian law. The Basic Principles and Guidelines state in paragraph 22(b) that the verification of facts and full public disclosure of the truth is a necessary part of reparation for the types of abuse covered by them. ${ }^{26}$

Several UN bodies, including the former Human Rights Commission, Human Rights Council and the General Assembly, have adopted resolutions stressing the importance of the right to truth in countering impunity and promoting human rights. ${ }^{27}$ In 2010 the General Assembly even proclaimed the 24th March as the 'International Day for the Right to the Truth concerning Gross Human Rights Violations and for the Dignity of Victims. ${ }^{28}$ These resolutions and soft-law instruments ${ }^{29}$ have been supported in practice by, amongst other things, the UN Human Rights Council's decision in 2011 to appoint a Special Rapporteur on the promotion of truth, justice, reparation and guarantees of non-recurrence. ${ }^{30}$

There is thus clearly a groundswell of international opinion in favour of recognizing a right to truth, ${ }^{31}$ but this does not translate straightforwardly into international legal rights and duties. Historical accounting may be achieved through a range of legal and administrative measures, including truth commissions ${ }^{32}$ and lustration, ${ }^{33}$ as well as through formal investigation, ${ }^{34}$ but not all are underpinned by a claimed 'right' to them. There is a thus a certain conceptual elusiveness - or expansiveness, even, to the right to truth,

\footnotetext{
${ }^{25}$ Adopted and proclaimed by UNGA Resolution 60/147 (16 December 2005), and also known as the 'Joinet/Orentlicher Principles'.

${ }^{26}$ For a discussion of the Basic Principles and Guidelines, also known as the van Boven/ Bassiouni Principles, see M Zwanenburg, 'The van Boven/Bassiouni Principles: An Appraisal' (2006) 24 NQHR 641.

27 Human Rights Commission Resolution 2005/66 (20 April 2005) UN Doc E/CN.4/RES/2005/ 66; Human Rights Council Resolution 12/12 (October 12 2009) UN Doc A/HRC/RES/12/12; UNGA Resolution 68/165 (18 December 2013) UN Doc A/RES/68/165.

${ }^{28}$ See UNGA Resolution 65/196 (21 December 2010) UN Doc A/RES/65/196.

${ }^{29}$ On the nature of soft law, and the Basic Principles and Guidelines as an example thereof, see D Shelton, 'Soft Law' in D Armstrong (ed), Routledge Handbook of International Law (Routledge 2008) 72.

${ }^{30}$ Human Rights Council Resolution 18/7 (13 October 2011) UN Doc A/HRC/RES/18/7.

31 Of course, there are exceptions to this trend, including the Spanish pacto del olvido (pact of forgetting, in respect of the Franco regime), but even this may be dissipating: M Davis, 'Is Spain Recovering Its Memory? Breaking the "Pacto del Olvido" (2005) 27 HRtsQ 858.

${ }^{32}$ See P Hayner, Unspeakable Truths: Transitional Justice and the Challenges of Truth Commissions (2nd edn, Routledge 2011).

${ }^{33}$ On lustration see A Czarnota, 'Lustration, Decommunisation and the Rule of Law' (2009) 1 Hague Journal on the Rule of Law 307; JA Sweeney, The European Court of Human Rights in the Post-Cold War Era (Routledge 2012) 127.

${ }^{34}$ It is also worth noting the impact of non-State actors in this regard: Hayner (n 32) 16; L Bickford, 'Unofficial Truth Projects' (2007) 29 HRtsQ 994; G Visoka, 'Arrested Truth: Transitional Justice and the Politics of Remembrance in Kosovo' (2016) 8 Journal of Human Rights Practice 62.
} 
not least of all owing to it often being said to have both individual and collective dimensions. ${ }^{35}$ There may be vastly differing, and conflicting, techniques to vindicate each dimension. Indeed, this was precisely the situation faced by the South African Constitutional Court in 1996 when the family of murdered activist Steve Biko, supported by the Azanian Peoples Organization (AZAPO), argued that the power of the South African Truth and Reconciliation Commission to grant amnesties breached their right to have 'justiciable disputes settled by a court of law'.36

There is also a certain amount of legal elusiveness about the right to truth. The 2006 UN Human Rights Commission 'Study on the right to truth' claimed to have found that the right to truth was an, 'inalienable and autonomous right', ${ }^{37}$ but its analysis conflated the historical and the legal bases of the right ${ }^{38}$ and failed to engage with the recognized sources of public international law at all. ${ }^{39}$ This is important because treaty law in this field is scant: whilst the First Additional Protocol to the 1949 Geneva Conventions states that the implementation of the rules on missing persons and the remains of the deceased should be, 'prompted mainly by the right of families to know the fate of their relatives', ${ }^{40}$ a comprehensive right to truth would need to address circumstances outside of an international armed conflict; ${ }^{41}$ and whilst the International Convention for the Protection of All Persons from Enforced Disappearance enshrines that each victim has the right to know the truth regarding the circumstances of the disappearances, ${ }^{42}$ it is far from universally ratified, ${ }^{43}$ and not all claims for truth arise from disappearances. ${ }^{44}$

${ }^{35}$ UN Human Rights Commission, 'Study on the Right to Truth' (8 February 2006) UN Doc E/CN.4/2006/91 (hereafter '2006 Study') para 14.

${ }^{36}$ AZAPO v President of the Republic of South Africa 1996(4) SA 671 (CC). The Constitutional Court upheld the constitutionality of the Commission's power to grant amnesties.

372006 Study (n 35) 'Summary' and para 55.

${ }^{38}$ For example Section I of the 2006 Study is entitled, 'Legal and Historical Basis for the Right to Truth'. See 2006 Study (n 35) 4.

${ }_{39}$ Commonly understood to be stated authoritatively in art 38 Statute of the International Court of Justice (adopted 26 June 1945, entered into force 24 October April 1945) 3 Bevans 1179: see H Thirlway, 'The Sources of International Law' in M Evans (ed), International Law (4th edn, Oxford University Press 2014) 94.

40 Art 32, Protocol Additional to the Geneva Conventions of 12 August 1949, and relating to the Protection of Victims of International Armed Conflicts (adopted 12 December 1977, entered into force 7 December 1979) 1125 UNTS 3.

${ }^{41}$ Indeed this is expressly noted in the preamble to UN Human Rights Commission Res 2005/66 (n 27), which states that, 'adequate steps to identify victims should also be taken in situations not amounting to armed conflict, especially in cases of massive or systematic violations of human rights ...'. See also Panepinto (n 18) 3.

${ }^{42}$ Art 24(2), International Convention for the Protection of All Persons from Enforced Disappearance (adopted 20 December 2006, entered into effect 23 December 2010) 2716 UNTS 3.

${ }_{43}$ There are currently 56 States Parties to the Convention, and a total of 96 signatory States. It has not been ratified by Russia, China, the USA, or the UK: UN Treaty Series, 'International Convention for the Protection of All Persons from Enforced Disappearance' $<\mathrm{https}$ ://treaties.un. org/pages/ViewDetails.aspx?src=IND\&mtdsg_no=IV-16\&chapter=4\&clang=_en $>$.

${ }_{44}$ See also Panepinto (n 18) 5. 
It has been suggested, in the alternative, that the right to truth could be founded in customary international law, ${ }^{45}$ in part based upon the existence of 'concurring jurisprudence' in international human rights law. ${ }^{46}$ However as hinted above and detailed below, the existing human rights jurisprudence is not entirely 'concurring' - especially in respect of temporal jurisdiction over pre-transition human rights violations. Moreover there are well-known disagreements on the formation and identification of customary international law. ${ }^{47}$ Yasmin Naqvi's comprehensive 2006 analysis of the right to truth in international law $^{48}$ applied Theodore Meron's generous approach to the formation of customary international human rights law, ${ }^{49}$ but still found that the right, 'stands somewhere on the threshold of a legal norm and a narrative device ... [S]omewhere above a good argument and somewhere below a clear legal rule'. In legal terms, Naqvi's suggestion that the right to truth might be a general principle of law ${ }^{50}$ is probably still the strongest claim that could be made for it in general public international law. ${ }^{51}$

International human rights jurisprudence may sidestep at least some of the elusiveness of a free-standing public international legal right to truth. Such jurisprudence derives from a series of self-contained treaty regimes with their own arbiters employing their own rules of interpretation, and where judicial activism may result in the discovery and acceptance of new principles - including on the extent of the arbiters' own temporal jurisdiction. ${ }^{52}$ There are certainly questions about the balance between textualist and evolutive ('living instrument') ${ }^{53}$

45 UN Human Rights Commission, 'Eighth Annual Report and List of States which, Since 1 January 1985, Have Proclaimed, Extended or Terminated a State of Emergency' (26 June 1995) UN Doc E/CN.4/Sub.2/1995/20*, para 40 (hereafter 'Despouy Report', after its author); SzokeBurke (n 6) 539.

46 Despouy Report (n 45).

47 Note the ongoing work of the International Law Commission on this topic, summarizing much of the existing practice and scholarship in this field: International Law Commission, 'Analytical Guide to the Work of the International Law Commission: Identification of Customary International Law' (ILC 30 June 2017) < http://legal.un.org/ilc/guide/1_13.shtml>. See also the discussion in Panepinto (n 18) 19ff. 48 Naqvi (n 6).

49 T Meron, Human Rights and Humanitarian Law as Customary Law (Clarendon 1989) 94. For criticism of this approach see B Simma and P Alston, 'The Sources of Human Rights Law: Custom, Jus Cogens and General principles' (1992) 12 AustYBIL 82.

51 Naqvi (n 6) 273.

52 E Bjorge, The Evolutionary Interpretation of Treaties (Oxford 2014), although note that at $168 \mathrm{ff}$ Bjorge argues that the evolutive approach to temporal jurisdiction taken in Silih v Slovenia (n 17) was superfluous as temporal jurisdiction could have been established on more traditional grounds.

${ }^{53}$ See Tyrer $v$ UK (App No 5856/72) (1978) 2 EHRR 1, para 31. Note also that art 32(2) ECHR and art 3(2) of the 1998 Protocol to the African Charter on Human and Peoples' Rights on the Establishment of an African Court on Human and Peoples' Rights expressly recognize the authority of each court to decide upon disputes as to its jurisdiction: Protocol to the African Charter (adopted 10 June 1998, entered into force 25 January 2004) <http://www.refworld.org/ docid/3f4b19c14.html $>$. Although, perhaps oddly, when the 1998 Protocol is replaced by the 2008 Protocol on the Statute of the African Court of Justice and Human Rights there will be no direct equivalent provision governing the new African Court: see Protocol on the Statute of the African Court of Justice and Human Rights (adopted 1 July 2008, not in force) <http://www. 
approaches, ${ }^{54}$ but these are capable of being resolved (albeit sometimes over some time) $)^{55}$ by the relevant enforcement bodies. Whilst the regimes are self-contained they may provide inspiration to each other through judicial collaboration and trans-judicial dialogue, both in the development of substantive standards as well as forms of legal reasoning. ${ }^{56}$ Such dialogue may serve to guard against excessive legal fragmentation, ${ }^{57}$ and the resulting broadly supranational law of human rights may fairly be described as cosmopolitan in nature. ${ }^{58}$

In the next sections we shall examine the extent to which global and regional human rights enforcement bodies have, in both their 'general' and 'transitional' jurisprudence, developed functionally equivalent approaches to the right to truth. It is shown that although there is much in common between the different human rights regimes, there are significant anomalies. The article will not address the related but distinct issue of human rights enforcement bodies being called upon, expressly or impliedly, to settle major debates about the past (such as the lawfulness of the Soviet Union annexing the Baltic States in 1940; ${ }^{59}$ or whether the persecution of Armenians in 1915 amounted to genocide). ${ }^{60}$

\section{THE RIGHT TO TRUTH AT THE ICCPR HUMAN RIGHTS COMMITTEE}

\section{A. General Approach to the Right to Truth}

In its 1983 View in the case of Quinteros v Uruguay the ICCPR Human Rights Committee (HRC) not only found violations of the initial victim's rights in respect of her disappearance and presumed death, but also in respect of her mother stated that,

The Committee understands the anguish and stress caused to the mother by the disappearance of her daughter and by the continuing uncertainty concerning her

refworld.org/docid/4937f0ac2.html $>$. Whilst there is no formal equivalent to these provisions in the treaties founding the ICCPR Human Rights Committee and American Court of Human Rights, we shall see that there is no shortage of jurisprudence on those bodies' jurisdiction.

54 For further discussion of this principle see eg G Letsas, A Theory of Interpretation of the European Convention on Human Rights (Oxford University Press 2007).

55 Note eg Dembour's criticism of the slow evolution of rights for transsexuals in European human rights law: M Dembour, Who Believes in Human Rights? Reflections on the European Convention (Cambridge University Press 2006) 238.

56 See G Canivet, 'Trans-Judicial Dialogue in a Global World' in S Muller and S Richards (eds), Highest Courts and Globalisation (Hague Academic Press 2010).

57 Report of the Study Group of the International Law Commission, 'Fragmentation of International Law: Difficulties Arising from the Diversification and Expansion of International Law' (13 April 2006) A/CN.4/L.682.

58 HP Glenn, The Cosmopolitan State (Oxford University Press 2013) 244.

59 Note the opposing interventions of Russia and Lithuania on the annexation of the Baltic States in Kononov v Latvia (GC) (App No 36376/04) (2010) ECHR 667.

60 Note the Turkish intervention in Perinçek v Switzerland (GC) (App No 27510/08) (2016) 63 EHRR 6, discussing the Armenian genocide. 
fate and whereabouts. The author has the right to know what has happened to her daughter. In these respects, she too is a victim of the violations of the Covenant suffered by her daughter in particular, of article 7 [ICCPR]. ${ }^{61}$

This is the earliest articulation of a right to the truth (or right to know) in international human rights jurisprudence, ${ }^{62}$ and it is anchored in the right to freedom from torture, cruel or inhuman treatment. This finding has been influential upon the development of the Inter-American ${ }^{63}$ and European ${ }^{64}$ jurisprudence in respect of their equivalent rights, discussed further below. It also formed a central part of the basis of Orentlicher's interpretation of the HRC's jurisprudence, under which she found that, 'prosecution leading to an appropriate sanction is generally required when a disappearance, an extralegal execution, or torture is credibly alleged'. ${ }^{65}$ Thus, the Quinteros View is an important step towards demonstrating the connection between State obligations to investigate and prosecute, and an individual right to truth. The HRC has continued to show the importance of Article 7 ICCPR to the next of kin in cases of enforced disappearances, although not always expressly invoking the right to truth or the right to know. ${ }^{66}$

In the disappearance case of Saadoun v Algeria the HRC also examined the Article 2(3) ICCPR right to a remedy. Following a 2005 referendum the Algerian authorities had promulgated a 'Charter for Peace and National Reconciliation', which prohibited, with the threat of imprisonment, the initiation of legal proceedings in respect of the 'national tragedy', viz. the 1991 to 1999 Algerian civil war that provided the backdrop to the disappearance at issue. ${ }^{67}$ The State had argued that the Charter, which did offer a route to compensation in relation to presumed deaths connected to the

${ }^{61}$ Quinteros v Uruguay (Comm No 107/1981), View of 21 July 1983, UN Doc CCPR/C/OP/2, 138 (1990) para 14 (emphasis added).

62 Although to be fair as far back as 1977 the Inter-American Commission on Human Rights had commented that disappearances affect not only the rights of the disappeared person, but also constituted 'a true form of torture for the victims' family and friends because of the uncertainty that they experience as to the fate of the victim': Inter-American Commission on Human Rights, 'Annual Report of the Inter-American Commission on Human Rights 1977', OEA/Ser.L/V/II.43, Doc. 21 corr. 1 (1978) Pt II; note also the discussion in Inter-American Commission on Human Rights, The Right to Truth in the Americas (n 4) 28.

63 See the 'Street Children' (Villagran-Morales et al.) v Guatemala, Inter-American Court of Human Rights (19 November 1999) Series C No 63, para 176; Bámaca Velásquez v Guatemala (Merits), Inter-American Court of Human Rights (25 November 2000) Series C No 70, para 164; Myrna Mack Chang v Guatemala, Inter-American Court of Human Rights (25 November 2003) Series C, No 101, para 274.

${ }^{64}$ See Kurt v Turkey (App No 24276/94) (1999) 27 EHRR 373, para 130ff.

65 Orentlicher (n 11) 2575.

66 See eg Sarma v Sri Lanka (Comm No 950/2000), View of 16 July 2003, UN Doc CCPR/C/78/ D/950/2000 (2003) para 9.5; Boucherf v Algeria (Comm No 1196/2003), View of 30 March 2006, UN Doc CCPR/C/86/D/1196/2003 (2006) para 9.7; Saadoun v Algeria, (Comm No 1806/2008), View of 22 March 2013, UN Doc CCPR/C/107/D/1806/2008 (2013) para 8.5.

67 See Saadoun (n 66) para 2.12; BBC, 'Algeria Country Profile' (BBC, 27 January 2017) $<\mathrm{http}: / /$ www.bbc.co.uk/news/world-africa-14118852>. 
'national tragedy', ${ }^{68}$ reflected a, 'desire to avoid confrontation in the courts, media outpourings and political score-settling' ${ }^{69}$ Whatever the merits of this approach, the failure to conduct a thorough and effective investigation was found to constitute a violation of Article 2(3) ICCPR. ${ }^{70}$ This is significant because imposing investigatory duties in this way also assists in vindicating the right to truth for the next of kin: in fact within the Inter-American system the right to truth has been expressly 'subsumed' within the right to a remedy, as we shall see below. ${ }^{71}$

The right to a remedy in the ICCPR has some important limitations to it. Whilst, as seen in the Saadoun View immediately above, failure by a State party to investigate allegations of human rights violations can in and of itself give rise to a separate breach of the Covenant, ${ }^{72}$ the Article 2 ICCPR right to a remedy may only be raised in respect of an already established violation of another substantive right within the HRC's jurisdiction. ${ }^{73}$ This is significant in relation to the discussion of admissibility ratione temporis below.

It is worth noting that the HRC also usually invokes Article 2(3) ICCPR towards the end of the text of its Views (whether or not it has found a separate violation of it) as the foundation for the State's obligation to provide a remedy for whichever other rights have been violated. ${ }^{74}$ This has parallels with the reparations phase of cases at the Inter-American Court, based on Article 63(1) of the American Convention on Human Rights, in which the right to truth expressly plays a significant role. ${ }^{75}$ Likewise it is comparable to the remedial obligations emanating from Article 46 of the European Convention on Human Rights, under which Contracting Parties undertake to abide by the final judgment of the European Court in respect of cases to which they are party. These provisions are discussed further below.

This section has shown that the right to truth has two main dimensions in the HRC's general jurisprudence, expressly underpinning findings on inhuman treatment of the next of kin; and implicitly doing so in relation to the right to a remedy.

\section{B. Admissibility ratione temporis and Transitional Jurisprudence}

The HRC has conclusively held that, where there are no issues of admissibility ratione temporis, successor regimes may be held responsible for the actions of their totalitarian predecessors. For example in the case of Hugo Rodriguez $v$

68 Saadoun (n 66) para 4.6.

71 See the discussion at (n 115).

69 ibid, para 4.7.

70 ibid, para 8.8 .

72 See also HRC, 'General Comment 31: The Nature of the General Legal Obligation Imposed on States Parties to the Covenant' UN Doc CCPR/C/21/Rev.1/Add. 1326 (2004).

73 H.G.P. \& S.P. v Trinidad and Tobago, (Comm No 268/1987), Decision of 3 November 1987 , UN Doc CCPR/C/37/D/268/1987 (1989) para 6.2.

74 See Saadoun (n 66) para 10; Sankara v Burkino Faso (Comm No 1159/2003), View of 28 March 2006, UN Doc CCPR/C/86/D/1159/2003 (2006) para 14.

75 See Myrna Mack Chang (n 63) para 274, discussed in the text at (n 101). 
Uruguay, decided in 1994 and concerning events commencing in 1983, the HRC found that it, "could not agree with the State party that it has no obligation to investigate violations of Covenant rights by a prior regime'. ${ }^{76}$ Uruguay had ratified the ICCPR and its First Optional Protocol in 1970, and so the HRC clearly had temporal jurisdiction.

The Hugo Rodriguez case did not address the right to truth expressly, but it and similar cases demonstrate that successor regimes may have significant investigatory duties under the Covenant (in which the right to truth may be subsumed) when admissibility ratione temporis is not an issue. In cases where the HRC has addressed admissibility ratione temporis the right to a remedy will not be available for pre-ratification human rights abuses that are otherwise outside the temporal jurisdiction of the HRC, which is in sharp contrast to the Inter-American jurisprudence discussed below. This can be seen in the 1990 admissibility decision in S.E. v Argentina, ${ }^{77}$ concerning a 1976 disappearance during the so-called 'dirty war'. The Covenant and its Optional Protocol only entered into force for Argentina in November $1986^{78}$ so there were no substantive violations to which the right to a remedy could be attached, and the communication was declared inadmissible. ${ }^{79}$

The S.E. decision is undoubtedly harsh. In addition to invoking Article 2, the author of the complaint also protested that the disappearance of her children was never fully investigated ${ }^{80}$ Well before the S.E. decision the HRC had held that it is empowered to consider a communication when the measures complained of, although they occurred before the crucial date, continued to have effects which themselves constitute a violation of the Covenant after that date. ${ }^{81}$ Even in the S.E. decision the HRC reminded Argentina that, 'it is under an obligation, in respect of violations occurring or continuing after the entry into force of the Covenant, thoroughly to investigate alleged violations and to provide remedies where applicable, for victims or their dependants' ${ }^{82}$ Given that the author's children were still missing it seems strange that there were no continuing violations in this case.

The HRC jurisprudence on this point is, however, not altogether consistent, and in other cases it has accepted that a disappearance can have continuing effects. In Sarma v Sri Lanka, decided on the merits in 2003, the HRC

${ }^{76}$ Hugo Rodriguez v Uruguay, (Comm No 322/1988), View of 19 July 1994, UN Doc CCPR/C/ 51/D/322/1988 (1994) para 12.3; see also Blanco v Nicaragua (Comm No 328/1988), View of 20 July 1994, UN Doc CCPR/C/51/D/328/1988 (1994) para 5.3, where the HRC found that, "the authorities of any State party to the Covenant are under an obligation to investigate alleged human rights violations and to make available appropriate judicial remedies and compensation to victims of such violations, even if they are attributable to a previous administration'.

77 S.E. v. Argentina, (Comm No 275/1988), Decision of 26 March 1990, UN Doc CCPR/C /38/ D/275/1988 (1990).

79 See also RAVN et al. v Argentina, (Comm Nos 343, 344 and 345/1988), Decision of 26 March 1990, UN Doc CCPR/C/38/D/344/1988 (1990). $\quad{ }_{80}$ S.E. (n 77) para 3.2.

${ }^{81}$ Lovelace v Canada, (Comm No R.6/24), View of 30 July 1981, UN Doc Supp. No 40 (A/36/ $40)$ at $166(1981)$ para 7.3 .

82 S.E. (n 77) para 5.4. 
examined a complaint involving the author and his son's removal from their home, by the military, in 1990, after which the son remained missing. ${ }^{83}$ The Optional Protocol only entered into effect for Sri Lanka in 1997, ${ }^{84}$ and Sri Lanka had also entered a declaration restricting the HRC's competence to events following the entry into force of the Optional Protocol. Despite this, for the purposes of admissibility, the HRC accepted that the author's allegations may have contained violations that 'occurred or continued' after the Optional Protocol entered into force for Sri Lanka. ${ }^{85}$ On the merits the HRC found that the son's apparently continuing detention revealed a violation of Article 9 ICCPR 'in its entirety' (right to liberty and security of the person), ${ }^{86}$ as well as a violation of Article 7 both with regard to the son's indefinite incommunicado detention and the next of kin's anguish and stress. ${ }^{87}$ The violation of Article 7 in respect of the next of kin was in recognition of the continuing uncertainty concerning the son's fate and whereabouts, which was the source of anguish and stress. ${ }^{88}$ The HRC was therefore able to invoke Article 2(3) to require Sri Lanka to provide an effective remedy. ${ }^{89}$ Thus, in the Sarma View, both dimensions of the right to truth were mutually reinforcing and resulted in a clear obligation to investigate a disappearance that commenced before the crucial date.

There is a further strand to the HRC's jurisprudence on continuing violations, which may also impact upon the right to truth in transitional contexts. In addition to the 'occurred or continued' formulation noted above, the HRC has also stated that,

A continuing violation is to be interpreted as an affirmation, after the entry into force of the Optional Protocol, by act or by clear implication, of previous violations by the State party..$^{90}$

It was in this way that, in its 2006 View in Mariam Sankara and others $v$ Burkina Faso, ${ }^{91}$ the HRC established temporal jurisdiction in respect of the alleged inhuman treatment of the family members of the assassinated president of Burkina Faso, Thomas Sankara, who was killed in 1987. Sankara himself had seized power in 1983, and Burkina Faso only began

\footnotetext{
83 Sarma v Sri Lanka (n 66) para 2.1ff. Note that the author actually thought he caught a glimpse of his son in a military van in 1991, but never subsequently.

$84 \mathrm{ibid}$, para 1.7. But note that the ethnic conflict in Sri Lanka continued until the military defeat of the 'Liberation Tigers of Tamil Eelam' in 2009, so this is hardly a paradigmatic 'transitional' case. For a basic timeline see BBC, 'Sri Lanka Country Profile' (BBC, 18 April 2017) <http://www.bbc. co.uk/news/world-south-asia-11999611>. $\quad 85$ ibid, para 6.2. $\quad{ }_{87}$ ibid, para 9.4. 87 ibid, para 9.5. 88 ibid para 9.5.

90 Konye v Hungary, (Comm No 520/1992), Decision of 4 April 1994, UN Doc CCPR/C/50/D/ $520 / 1992$ (1994) para 6.4. A slightly different formulation has occasionally also been used, according to which, 'A persistent violation is understood to mean the continuation of violations which the State party committed previously, either through actions or implicitly': see Kurowski v Poland, (Comm No 872/1999), Decision of 18 March 2003, UN Doc CCPR/C/77/D/872/1999, para 6.4 .

91 Sankara (n 74).
} 
transitioning to democracy in the $1990 \mathrm{~s},{ }^{92}$ in part evidenced by the ICCPR and the Optional Protocol entering into force for Burkina Faso in 1999. The HRC separated the claims in respect of Thomas Sankara's rights from those of his family. Although Thomas Sankara's death in 1987 may have involved the violation of several articles of the Covenant, complaints about it were inadmissible ratione temporis. ${ }^{93}$ However, as to his next of kin's rights, the failure to conduct an inquiry into the death, and the continued failure to correct Sankara's death certificate (which quite falsely stated that he died of natural causes) gave rise to alleged violations after the entry into force of the Covenant. ${ }^{94}$ Thus on the merits the HRC found a violation of Article 7 ICCPR in respect of the anguish caused by the lack of investigation into the situation and, citing Quinteros, noted that Thomas Sankara's family had 'the right to know the circumstances of his death'. ${ }^{95}$ In this way the HRC's transitional jurisprudence upheld the right to truth in respect of events some way prior to Burkina Faso's commencement of transition to democracy.

The requirement, in some cases, for some form of affirmation or perpetuation of a violation that occurred prior to the crucial date has led to Views that are difficult to reconcile with those based on the 'occurred or continued' formulation of continuing violations. For example, in the 2009 decision in Cifuentes $v$ Chile, the HRC found that the author's complaint about a disappearance that began in 1981 (before Chile ratified the Optional Protocol) was inadmissible because the author had made, 'no reference to any action by the State party after [the crucial date] that would constitute a perpetuation by the State party of the enforced disappearance of her son'. ${ }^{96}$ Chile had ratified the Optional Protocol with a declaration very similar to that seen in the Sarma case, restricting the competence of the HRC to acts after the Protocol came into effect for Chile. ${ }^{97}$ Yet, in the Sarma case, we saw that the HRC identified that the disappearance gave rise to facts 'occurring or continuing' after the crucial date, which disclosed violations of the Covenant.

Whilst the Sarma View was adopted unanimously, there was significant dissent in the Cifuentes decision. The most striking dissent was by HRC members Keller and Salvioli, according to whom,

92 See BBC, 'Burkina Faso profile - timeline' (BBC, 8 June 2017) <http://www.bbc.co.uk/ news/world-africa-13072857>.

93 ibid, para 6.2, summarizing the earlier admissibility decision. $\quad 94$ ibid, para 6.3.

95 ibid, para 12.2 .

96 Cifuentes $v$ Chile, (Comm No 1536/2006), Decision of 28 July 2009, UN Doc A/64/40 vol II (2009), Annex VIII.J, 491, para 8.5; see also a virtually identical inadmissibility finding in Yurich v Chile, (Comm No 1078/2002), Decision of 2 November 2005, UN Doc CCPR/C/85/D/1078/2002 (2005), para 6.4 .

97 Indeed, the declaration in Cifuentes (ibid) is notable because, despite being couched as a limitation on the HRC's jurisdiction, its terms were that the HRC competence would apply, 'in respect of acts occurring after the entry into force for [Chile] of the Optional Protocol [in August 1992] or, in any event, to acts which began after 11 March 1990'-ie over two years before the Protocol came into effect for Chile. 
The practice of enforced disappearance has given rise to the formulation of new rights and their introduction, through evolutive interpretation, into these general [human rights] instruments; the 'right to the truth' is one example.

They continued that under the ICCPR the right to truth,

arises in connection with the right to an effective remedy (art. 2, para. 3(a)), read in conjunction with the general obligation to respect and to ensure to all individuals the rights recognized in the Covenant ...

[The] right to the truth entails the right to obtain a clarification from the competent State bodies of the events constituting violation(s) and the persons responsible for them. Accordingly, the State must undertake an effective investigation of enforced disappearances in order to identify, prosecute and punish the perpetrators and instigators of such violations.

Members Keller and Salvioli also questioned why the majority had not explored the case from the perspective of the author's rights under Article 7 ICCPR.

From this section we can conclude that the status of the right to truth in the transitional jurisprudence of the HRC is somewhat mixed. Whilst the Quinteros line of cases (on denial of the next of kin's 'rights to know' as inhuman treatment) has been applied to historical disappearances and killings, such as in the Sarma and Sankara cases, in others such as S.E. and Cifuentes this dimension was omitted altogether. Likewise there seems to be disagreement about the correct test for establishing temporal jurisdiction, with some Views and decisions focusing on whether there are effects that have 'occurred or continued' after the crucial date; and others requiring an act of affirmation. Moreover, the Article 2(3) ICCPR right to a remedy may only be invoked alongside another established violation, and thus cannot be used alone as the foundation for gaining the truth about alleged abuse occurring before the crucial date.

The View in Sarma and the dissents in the Cifuentes decision present a more preferable view of continuing obligations arising from disappearances, which most effectively secures the rights of the next of kin, and also more closely resembles the approach of the Inter-American Court discussed in the next section. Indeed we saw that in Cifuentes dissent HRC members Keller and Salvioli expressly linked Article 2(3) ICCPR to the right to truth. In 2011 Keller became a judge at the European Court of Human Rights, and further below we shall see that, via contributing to two separate opinions in particular, ${ }^{98}$ judge Keller has continued to advocate for greater recognition of the right to truth.

\footnotetext{
98 See the joint concurring opinion of Judges Tulkens, Spielmann, Sicilianos and Keller in ElMasri v the former Yugoslav Republic of Macedonia (App No 39630/09) (2013) 57 EHRR 25 and the joint partly dissenting opinion of Judges Ziemele, de Gaetano, Laffranque and Keller in Janowiec and Others v Russia (GC) (App Nos 55508/07 and 29520/09) (2014) 58 EHRR 30. These are discussed further below.
} 


\section{THE RIGHT TO TRUTH IN THE INTER-AMERICAN HUMAN RIGHTS SYSTEM}

\section{A. General Approach to the Right to Truth}

The development of the right to truth in the Inter-American human rights system is intertwined with its approach to the phenomenon of enforced disappearances. In its first judgment in contentious proceedings, in the case of Velásquez Rodríguez v Honduras, the Inter-American Court (IACtHR) found that enforced disappearances cause, 'a multiple and continuous violation of many rights under the [American Convention on Human Rights (ACHR)]'. ${ }^{99}$ These include the right to personal liberty, right to life, and right to integrity of the person (including freedom from torture, inhuman or degrading treatment: Article 5 ACHR). Citing the overarching Article 1 duty to ensure respect for human rights, the IACtHR found that the duty to investigate disappearances 'continues as long as there is uncertainty about the fate of the person who has disappeared'. 100

Just as with the HRC, the finding that disappearances have a continuing dimension will be important to the discussion of admissibility ratione temporis; and we shall return to this below. For now, it is important to emphasize the continuing remedial obligations imposed upon Honduras through Article 63(1) ACHR because, in later cases, these have been expressly connected to the right to truth. The IACtHR has identified that the right to truth, 'constitutes an important means of reparation', creating expectations for both for the next of kin and society as a whole; such that there must be an effective investigation of grave human rights violations, which must be made known to the public. ${ }^{101}$ Indeed this has led not only to detailed guidance on the scope of investigations that must be carried out, but also on public acknowledgements and memorialization. ${ }^{102}$ Interestingly in its findings on investigatory obligations as an act of reparation the IACtHR has stated that the work of a truth commission, "neither completes nor substitutes for the State's obligation to establish the truth and to ensure the judicial determination of individual or State responsibilities also by judicial proceedings,'103 - although such initiatives can, 'contribute to the construction and preservation of the historical memory'. ${ }^{104}$

\footnotetext{
99 Velásquez Rodríguez v Honduras, Inter-American Court of Human Rights (29 July 1988) Series C No 4, para 155.

100 ibid, para 181.

101 Myrna Mack Chang (n 63) paras 274-275; see also Bámaca-Velásquez v Guatemala (Reparations and Costs), Inter-American Court of Human Rights (22 February 2002) Series C No 91, para $73 \mathrm{ff}$.

${ }_{102}$ See Rodríguez Vera et al. v Colombia, Inter-American Court of Human Rights (14 November 2014) Series C No 287, para 570ff, including the requirement that the respondent State prepare, exhibit and disseminate an audio-visual documentary about the events of the case. In the Myrna Mack Chang case, amongst several other measures of reparation, the IACtHR required that a well-known street or square in Guatemala City be named in honour of the victim: Myrna Mack Chang (n 63) para 286.

${ }_{103}$ See eg The Massacres of El Mozote and nearby places $v$ El Salvador, Inter-American Court of Human Rights (25 October 2012) Series C No 252, para 316.

104 Rodriguez Vera (n 102) para 88.
} 
Turning now to findings on the merits, in common with the HRC the InterAmerican system has recognized that the failure to expose the truth about gross violations of human rights may cause free-standing human rights violations in respect of the next of kin. Again like the HRC this jurisprudence has two principal dimensions, ${ }^{105}$ involving both the right to humane treatment and the right to a remedy.

The IACtHR's approach to the Article 5 ACHR right to humane treatment is both formally and functionally comparable to the HRC's approach to Article 7 ICCPR in the Quinteros View. Thus the IACtHR has held that, 'the violation of the mental and moral integrity of the next of kin is precisely a direct consequence of the forced disappearance'. ${ }^{106}$ In this regard the IACtHR has taken into account circumstances in which the respondent State has obstructed the next of kin's 'efforts to learn the truth of the facts'. ${ }^{107}$

Whilst the Article 5 jurisprudence developed in respect of disappearances, it has been applied to other forms of human rights violation. Thus, in the Barrios Family case, concerning a series of killings by the Venezuelan authorities, the ACtHR reiterated that, 'the next of kin of the victims of human rights violations may, in turn, be victims'. ${ }^{108}$ In this way continued impunity, resulting from a lack of judicial response to clarify the facts of a massacre, can constitute a 'new traumatic impact', ${ }^{109}$ capable of causing infringement of Article 5 ACHR in respect of survivors and next of kin. ${ }^{110}$ Whilst the connection to the right to truth is not express, this line of jurisprudence is still significant because it mirrors the jurisprudence at the HRC that does refer to the 'right to know'. ${ }^{111}$

The second dimension of the ACtHR's jurisprudence relating to the right to truth is where the next of kin have complained about a lack of investigation and information, using Articles 8 and 25 taken together (the right to a fair trial and right to judicial protection), in relation to the overarching Article 1 obligation to respect and ensure rights. This dimension is functionally comparable to, but

\footnotetext{
105 For the sake of thoroughness, a couple of outlying cases need to be acknowledged. First, in the case of Gudiel Álvarez et al. v Guatemala, Inter-American Court of Human Rights (20 November 2012) Series C No 253 the IACtHR made a rare express art 5 finding on the right to truth, where the State had failed to provide important information to a truth commission established after the end of the Guatemalan civil war. The failure to cooperate fully with the truth commission (that the State itself had established) prevented family members from knowing the 'historical truth', and amounted to a further violation of art 5 ACHR. Second, in the case of Gomes Lund et al. v Brazil, InterAmerican Court of Human Rights (24 November 2010) Series C No 219 the specific facts of the case led to the IACtHR examining the right to truth within arts 8 and 25 ACHR alongside art 13 - the right to free expression, and the freedom to seek, receive, and impart information and ideas of all kinds. Nevertheless, the IACtHR does not generally underpin its findings on the right to truth with art 13 ACHR. 106 Bámaca Velásquez (Merits) (n 63) para 160.107 ibid, para 165.

108 The Barrios Family v Venezuela, Inter-American Court of Human Rights (24 November 2011) Series C No 237, para 301.

109 The 'Las Dos Erres' Massacre v Guatemala, Inter-American Court of Human Rights (24 November 2009) Series C No 211, para 213.

111 Quinteros (n 61) para 14.
} 
more far-reaching than, the obligations emanating from the right to a remedy in the ICCPR and, in the Inter-American system, the right to truth has been invoked more expressly. The Inter-American Commission has stated that the general obligation in Article 1 ACHR entails that "the "right to the truth" arises as a basic and indispensable consequence for all States Parties', 112 having both individual and collective dimensions. ${ }^{113}$ The IACtHR, however, has thus far declined to recognize the right to truth as an autonomous right (although the Concurring Opinion of Judge Eduardo Ferrer Mac-Gregor Poisot in the recent case of Rodriguez Vera et al. $v$ Columbia makes a strong case for it). ${ }^{114}$ Instead, the IACtHR has frequently repeated that,

the right to the truth is subsumed in the right of the victim or his next of kin to obtain clarification of the facts relating to the violations and the corresponding responsibilities from the competent State organs, through the investigation and prosecution established in Articles 8 and 25 of the Convention. ${ }^{115}$

This is clear also in cases on other forms of human rights violation (ie in addition to disappearances). Thus amongst its findings on Articles 8 and 25 ACHR in the Myrna Mack Chang case, the IACtHR examined the way in which the Guatemalan judicial system had allowed the State to delay proceedings in relation to the extra-legal execution of a prominent anthropologist as part of a covert military intelligence operation, in $1990 .{ }^{116}$ The IACtHR observed that the failure to abide by the standards required by Articles 8 and 25 ACHR gave rise to a violation of the international obligation of the State to prevent and protect human rights; and it had also, 'abridge[d] the right of the victim and the next of kin of the victim to know the truth of what happened'. ${ }^{117}$

\section{B. Admissibility ratione temporis and Transitional Jurisprudence}

In the Velásquez Rodríguez v Honduras judgment the IACtHR established that responsibility for human rights violations exists independently of changes of government, even where the new government, 'may be much more respectful of those rights than that of the government in power when the violations occurred'.118 Thus, in Ruti Teitel's analysis the duties recognized in Velásquez Rodríguez were able to 'transcend and bridge' the different regimes. ${ }^{119}$ Likewise both Roht-Arriaza and Orentlicher noted the IACtHR's findings in Velásquez Rodríguez as part of their evidence in favour of the existence of a duty to investigate and prosecute grave violations of human

112 Lucio Parada Cea et al. v El Salvador, Inter-American Commission on Human Rights (27 January 1999) Report No 1/99, OEA/Ser.L/V/II.106, doc 6 rev, para 150.

113 ibid, para $151 . \quad{ }_{114}$ Rodríguez Vera (n 102).

115 Bámaca Velásquez v Guatemala (Merits) (n 63) para 201 (emphasis added); see also Chumbipuma Aguirre et al. v Peru (the Barrios Altos Case), Inter-American Court of Human Rights (14 March 2001) Series C No 75, para 48; see also similar language in Rodríiguez Vera (n 102) para 509 amongst others.

117 ibid, para 211. 118 Velásquez Rodríguez (n 99) para $184 . \quad 119$ Teitel (n 2) 125. 
rights. ${ }^{120}$ However, Honduras had ratified the ACHR in 1977 and accepted the contentious jurisdiction of the IACtHR from 9 September 1981 - just before the enforced disappearance of Manfredo Rodríguez on 12 September 1981. Thus, there was no question of inadmissibility ratione temporis. Nevertheless the recognition that, where there are no temporal barriers to jurisdiction, successor regimes have investigatory obligations is both significant and comparable to that seen at the HRC in Hugo Rodriguez v Uruguay, noted above.

Decided on the merits in 1998, the case of Blake v Guatemala concerned the disappearance and killing of a US journalist, Nicholas Blake, and his photographer Griffith Davis in 1985. Guatemala only accepted the contentious jurisdiction of the IACtHR in 1987, ${ }^{121}$ after the military junta of General Efraín Ríos Montt had been overthrown (but whilst the country was still embroiled in its civil war, which lasted from 1960 to 1996). ${ }^{122}$ In this case, there was a very real issue of admissibility. The IACtHR resolved it ${ }^{123}$ by accepting that even though it would not have jurisdiction to attribute State responsibility for violations of Blake's right to liberty under Article $7 \mathrm{ACHR}^{124}$ or his right to life under Article 4, ${ }^{125}$ the disappearance marked the beginning of a continuing situation, ${ }^{126}$ involving 'actions and effects' after the crucial date, which could give rise to violations in respect of the next of kin. ${ }^{127}$ The IACtHR thus found a violation of Article 8 and Article 5 ACHR, in relation to Article 1 ACHR. ${ }^{128}$ In other words, both dimensions of the right to truth were, at least implicitly, vindicated (deriving from the right to a remedy and the right to humane treatment).

Whilst the Blake case did not expressly mention the right to truth, in later cases on disappearances where temporal jurisdiction has been established in a similar way, the right to truth has underpinned violations of Article 5, and Articles 8 and 25, in the same way as those cases without a temporal dimension noted in the previous section. ${ }^{129}$ It has even done so where States have reservations preventing the IACtHR from considering the continuing

120 Roht-Arriaza (n 10) 467; Orentlicher (n 11) 2576ff.

121 Blake v Guatemala (Merits), Inter-American Court of Human Rights (24 January 1998) Series C No 36, para 2. $\quad{ }^{122}$ BBC, 'Guatemala Country Profile' (BBC, 3 January 2017) <http:// www.bbc.co.uk/news/world-latin-america-19635877>.

${ }^{123}$ Note that the IACtHR examined admissibility ratione temporis in both its 1996 judgment on Preliminary Objections, and in the 1998 judgment on the merits, reaching the same result. See Blake (Merits) (n 121) and Blake v Guatemala (Preliminary Objections), Inter-American Court of Human Rights (2 July 1996) Series C No $27 .{ }^{124}$ Blake (Merits) (n 121) $82 . \quad{ }^{125}$ ibid, para 86. 126 ibid, para 67.

127 It is also worth mentioning the Separate Opinion of Judge AA Cançado Trindade in Blake (Merits) (n 121): in the case of forced disappearances he argued against the application of 'a rigid postulate of the law of treaties' (namely the rules on admissibility ratione temporis). 'Human rights', he argued, 'are demanding a revitalisation of the law of treaties.'

${ }_{128}$ Blake (Merits) (n 121) para 124. Note that there was no violation of art 25 ACHR in this case, for the reasons given in paras 98-104.

129 See eg Heliodoro Portugal v Panama, Inter-American Court of Human Rights (12 August 2008) Series C No 186, paras 146-147 on arts 8 and 25, and para 175 on art 5; Gomes Lund (n 105) para 200 on arts 8 and 25 , and para 242 on art 5. 
effects of events prior to acceptance of the contentious jurisdiction of the court: the post-acceptance acts or omissions of the State can still be 'independent facts' sufficient to establish a free-standing violation of the ACHR in respect of the next of kin. ${ }^{130}$

This is crucial because it has allowed the IACtHR also to vindicate the right to truth through findings on Article 5, and Articles 8 and 25 ACHR, concerning the failure to investigate human rights violations before the crucial date other than disappearances (ie where the triggering event is 'instantaneous' rather than continuing). This can be seen in the judgment in Moiwana Community $v$ Suriname, ${ }^{131}$ concerning a massacre in 1986 during the military dictatorship of Dési Bouterse. ${ }^{132}$ Suriname argued that the complaint should be inadmissible because it had accepted the jurisdiction of the IACtHR in 1987 and only forced disappearances, which were not at issue, had a continuing dimension. ${ }^{133}$ To the contrary, the IACtHR held that once the allegation of a massacre had been made an obligation to investigate, prosecute and punish arose; and that the IACtHR was competent to assess compliance with that obligation from the date on which Suriname recognized the competence of the Court. Thus actions or omissions of the State in respect of its investigation into the massacre, commenced in 1989-after the crucial date, fell within the temporal jurisdiction of the IACtHR. ${ }^{134}$

On the merits, the State argued inter alia that when the investigation commenced in 1989 democracy was still not stable and, 'the climate was not suitable to carry out a sufficient investigation.' ${ }^{135}$ However, it went on, the investigation had resumed in 2002. ${ }^{136}$ The IACtHR responded firmly, holding in relation to Articles 8 and 25 ACHR that, 'Upon its accession to the American Convention in 1987, then, the first legal remedy Suriname was obligated to provide was a swift and exhaustive judicial investigation into the events of November 29, 1986.' 137 In examining the defective and protracted investigation into those events, the IACtHR acknowledged that, "victims of rights violations and their family members have a right to know the truth regarding those violations'. ${ }^{138}$ Thus the right to truth effectively underpinned a duty to investigate the misdeeds of a prior regime, even before the crucial date. This is an important legal development indeed. The IACtHR also

130 Serrano-Cruz Sisters v El Salvador (Preliminary Objections), Inter-American Court of Human Rights (23 November 2004) Series C No 118, para 84.

${ }_{131}$ Moiwana Community v Suriname, Inter-American Court of Human Rights (15 June 2005) Series C No 124.

${ }^{132}$ Under President Venetiaan, Suriname officially apologized for the massacred in 2006. However, Bouterse became president again in 2010, this time by democratic means, and was reelected in 2015: BBC, 'Suriname Country Profile' (BBC, 25 January 2017) <http://www.bbc.co. uk/news/world-latin-america-19997673>. $\quad 133$ Moiwana Community (n 131) para 34(e).

134 ibid, para 43.

135 ibid, para 138(e). Such claims by transitional States for special treatment in human rights law have been termed as claims for 'transitional relativism': see Sweeney (n 33 ) 3.

136 Moiwana Community (n 131) para 138(f). $\quad{ }^{137}$ ibid, para $146 . \quad 138$ ibid, para 147. 
reiterated that a long-standing absence of effective remedies is a source of suffering and anguish for victims and their family members, ${ }^{139}$ and found a violation of Article 5 ACHR in that regard (amongst other reasons). ${ }^{140}$

In summary the IACtHR has upheld the right to truth both by its findings on the right to humane treatment under Article $5 \mathrm{ACHR}$ and the right to a remedy under one or both of Articles 8 and 25 ACHR (taken together with Article 1). State acts or omissions after the crucial date may be 'independent facts' in respect of which the next of kin is able to vindicate procedural rights connected to the right to truth even where the triggering event is both instantaneous and prior to the crucial date. This has allowed the IACtHR to impose significant obligations upon transitional States emerging from periods of dictatorship.

\section{THE RIGHT TO TRUTH AT THE ECtHR}

\section{A. General Approach to the Right to Truth}

The right to truth has been comparatively slow to develop in the jurisprudence of the European Court of Human Rights (ECtHR). ${ }^{141}$ However we shall see that both dimensions of the right to truth that have been visible in the jurisprudence of the HRC and IACtHR are emerging in the jurisprudence on the European Convention on Human Rights (ECHR).

The ECtHR has been influenced by the HRC View in Quinteros, and has thus recognized that in certain circumstances the next of kin of a victim of human rights abuses may, themselves, become a victim of inhuman and degrading treatment. ${ }^{142}$ This approach is similar also to that of the IACtHR, as seen in Bámaca Velásquez. Thus on the face of it there is formally and functionally comparable jurisprudence on inhuman treatment across all three human rights regimes examined so far. However, the threshold for violating next of kin rights is comparatively high at the ECtHR. In the 1991 Çakıcı $v$ Turkey judgment the ECtHR declined to find a violation of Article 3 in respect of the brother of a disappeared person, noting that he had not witnessed the abduction; he had not 'born the brunt' of the work attempting to secure justice for his brother; and there were no 'aggravating factors'. ${ }^{143}$ In its 2001 judgment in the Cyprus v Turkey inter-State case the ECtHR further stated that,

the question whether a family member of a 'disappeared person' is a victim of treatment contrary to Article 3 will depend on the existence of special factors which give the suffering of the person concerned a dimension and character distinct from the emotional distress which may be regarded as inevitably caused to relatives of a victim of a serious human-rights violation ... ${ }^{144}$

\footnotetext{
139 ibid, para 94.

142 Kurt v Turkey (n 64) para 130ff.

143 Çakıcı v Turkey (App No 23657/94) (2001) 31 EHRR 5, para 99.

144 Cyprus v Turkey (App No 25781/94) (2002) 35 EHRR, para 156 (emphasis added).
} 
This approach, normalizing the 'inevitable distress' caused by human rights violations, fails to capitalize fully upon the notion that denial of access to the truth viewed through the prism of the next of kin's right to freedom from inhuman and degrading treatment can buttress investigative obligations derived from other rights (such as the right to a remedy). Moreover the ECtHR has developed the rather unfortunate principle that,

[W]hile a family member of a 'disappeared person' can claim to be a victim of treatment contrary to Article $3 \ldots$, the same principle would not usually apply to situations where the person taken into custody has later been found dead ... In such cases the Court would normally limit its findings to Article 2. ${ }^{145}$

In the admissibility decision in Gürtekin and others v Cyprus, the ECtHR confirmed that it would make a separate finding on Article 3 ECHR in respect of confirmed deaths only in 'very restricted circumstances'. ${ }^{146}$ Such circumstances might be where the next of kin were direct witnesses to the killing. ${ }^{147}$ The ECtHR therefore draws a clear line between a 'disappearance case' and a 'confirmed death case', in a way that is not at all reflective of developments at the IACtHR and HRC. This is surely an invidious position for the ECtHR to adopt. ${ }^{148}$

We now turn to the second dimension of the right to truth: the duty to investigate and prosecute which, at the HRC and IACtHR, was rooted in the right to a remedy. For the ECtHR the obligation to investigate human rights abuses is generally derived from the procedural 'limb' or 'aspect' of the applicable substantive right (ie the right to life (Article 2 ECHR), or freedom from torture (Article $3 \mathrm{ECHR}$ )) rather than the right to a fair hearing (Article 6 ECHR) or the right to an effective remedy (Article 13 ECHR). Articles 6 and 13 ECHR have been used more in respect of checking the remedial phase of domestic human rights litigation, with the ECtHR having established that wherever there is an 'arguable' grievance regarding a Convention right, there must be an effective domestic remedy allowing a 'competent national authority' to deal both with the substance of the complaint and to grant appropriate relief. ${ }^{149}$ Where a case has been examined from the perspective of Article 6, or where there has been substantial discussion of the adequacy of domestic remedies for admissibility purposes, the ECtHR

\footnotetext{
145 Tanll v Turkey (App No 26129/95) (2002) 35 EHRR 30, para 159; Jelić v Croatia (App No 57856/11) (2015) 61 EHRR 43, para 111.

${ }^{146}$ Gürtekin and others $v$ Cyprus (dec) (App Nos 60441/13, 68206/13 and 68667/13) ECHR 11 March 2014, para 34.

147 Shovgurov v Russia (dec) (App No 17601/12) ECHR 25 August 2015, para 75.

148 Of course, the other systems have looked into the nature of familial relationships in relation to claimed inhuman treatment of the next of kin. The IACtHR for example has drawn a distinction between those close family members who can be 'presumed' to have suffered harm to their mental and moral integrity, and other next of kin in relation to which it must evaluate whether particularly close ties existed. However this jurisprudence applies equally to disappearances and 'confirmed killings': see Barrios Family (n 108) para 302.

149 See eg Aksoy v Turkey (App No 21987/93) (1997) 23 EHRR 553, para 95.
} 
tends to conclude it is unnecessary to examine the case from the perspective of Article 13. ${ }^{150}$ Nevertheless, when it has examined the Article 13 right to a remedy it has held that it is wider than a Contracting State's obligation under Article 2 to conduct an effective investigation. ${ }^{151}$

Recent cases on the reprehensible practice of 'extraordinary rendition' have exemplified the practice of imposing investigatory duties through the relevant substantive right rather than the right to a remedy; whilst at the same time recognizing the close relationship between duties to investigate and the right to truth. The case of El-Masri v Macedonia was brought by a victim of extraordinary rendition. In its discussion of Article 3 ECHR the ECtHR Grand Chamber declared that it would set out to,

address another aspect of the inadequate character of the investigation in the present case, namely its impact on the right to the truth regarding the relevant circumstances of the case. In this connection it underlines the great importance of the present case not only for the applicant and his family, but also for other victims of similar crimes and the general public, who had the right to know what had happened. ${ }^{152}$

The Grand Chamber stressed that an adequate investigation of the circumstances was essential in maintaining public confidence in the authorities; and that the inadequate investigation in his case had prevented El-Masri 'from being informed what had happened'. ${ }^{153}$ Thus whilst the right to truth is 'subsumed' within the right to a remedy (implying a duty to investigate) in Articles 8 and 25 ACHR, here it is addressed through the procedural limb of Article 3 ECHR. Nevertheless the essence of the reasoning is functionally comparable (but note that this invocation of Article 3 ECHR is distinct from its other role, where the next of kin's anguish in respect of human rights abuses may give rise to a separate violation of Article 3). ${ }^{154}$

It is also important to observe that in El-Masri the applicant sought to rely upon his Article 10 ECHR right to 'receive and impart' information as the foundation for 'a right to be informed of the truth' regarding the circumstances that had led to the violations of his Convention rights. ${ }^{155}$ The ECtHR declared this aspect of the complaint manifestly ill-founded, as it overlapped with and had been addressed by the application of Article 3

150 See Akdivar and Others $v$ Turkey (App No 21893/93) (1997) 23 EHRR143, para 97; But see the concern expressed previously about this very approach in the Joint Separate Opinion of Judges Pinheiro and De Meyer in $W v U K$ (App No 9749/82)(1988) 10 EHRR 29. See also A Lee, 'Focus on Article 13 ECHR' (2015) 20 JR 33, 39.

151 Kaya v Turkey (App No 22729/93) (1999) 28 EHRR 1, para 107; Orhan v Turkey (App No 25656/94) ECHR 18 June 2002, ECHR 2002, para 384.

152 El-Masri (n 98) para 191 (emphasis added).

154 See Kurt v Turkey (n 64) paras 133-134, noted above. 
ECHR. ${ }^{156}$ This is directly comparable to the way in which the right to truth is 'subsumed' within Articles 8 and 25 ACHR by the ACtHR, but has been rejected as a free-standing right.

There is thus a clear recognition by the ECtHR that the right to truth is subsumed within the procedural limb of certain Convention rights, but that attempts to invoke it expressly will fail. However, in El-Masri there were lengthy separate opinions expressing divergent approaches to the right to truth. The Joint Concurring Opinion of judges Tulkens, Spielmann, Sicilianos and Keller in El-Masri called for a bolder application of Article 13 ECHR and criticized, 'the judgment's somewhat timid allusion to the right to the truth in the context of Article 3'.

Recall that whilst still a member of the ICCPR HRC, ECtHR Judge Keller had joined HRC member Salvioli in a dissent from the outcome of the Cifuentes inadmissibility decision, criticizing the majority's failure to uphold the right to truth. The Joint Concurring Opinion in El-Masri is a similar attempt to link the right to truth to the right to a remedy. However it should also be noted that in El-Masri the Joint Concurring Opinion of Judges Casadevall and López Guerra took exactly the opposite approach, and went so far as to describe the judgment's ('timid') discussion of the right to truth as 'redundant'.

Before examining the European approach to cases presenting challenges in terms of admissibility ratione temporis, it is necessary to identify the ECtHR's jurisprudence on historical human rights violations that are nevertheless within its temporal jurisdiction. For example in the 2007 judgment in Brecknell v UK, the Court examined the effectiveness of a 1999 investigation into three 1975 murders in Northern Ireland. ${ }^{157}$ The UK ratified the ECHR in 1951 and accepted the right of individual petition in $1966 .{ }^{158}$ Although the ECtHR found for the applicant it reasoned that,

the nature and extent of any subsequent investigation required by the procedural obligation would inevitably depend on the circumstances of each particular case and might well differ from that to be expected immediately after a suspicious or violent death has occurred.

The Court would also comment that there is little ground to be overly prescriptive as regards the possibility of an obligation to investigate unlawful killings arising many years after the events since the public interest in obtaining

156 El-Masri (n 98) paras 264-265. The same approach was taken in the case of Al Nashiri v Poland (App No 28761/11) (2015) 60 EHRR 16, even though the United Nations Special Rapporteur on the promotion and protection of human rights and fundamental freedoms while counteracting terrorism, who had been invited to address a public hearing in the case, argued that the right to truth also implicated Article 10 ECHR. See Al Nashiri, para 483.

157 Brecknell v UK (App No 32457/04) (2008) 46 EHRR 42, para 66.

158 Council of Europe, 'Chart of Signatures and Ratifications of Treaty 005' (Council of Europe, 28 June 2017) <http://www.coe.int/en/web/conventions/search-on-treaties/-/conventions/treaty/ $005 /$ signatures?p_auth=K81dNial $>$. 
the prosecution and conviction of perpetrators is firmly recognised, particularly in the context of war crimes and crimes against humanity. ${ }^{159}$

The differing procedural obligation for historical human rights violations has been observed also in respect of inadequate relaunched investigations into killings in Turkey, ${ }^{160}$ as well as killings and disappearances in Chechnya (Russia). ${ }^{161}$ The ECtHR has also observed that the extent of the duty to investigate may depend on the context, and therefore in the case of Al-Skeini $v$ the United Kingdom, observed that,

in circumstances of generalised violence, armed conflict or insurgency, obstacles may be placed in the way of investigators and ... concrete constraints may compel the use of less effective measures of investigation or may cause an investigation to be delayed. ${ }^{162}$

The investigative duty is clear, but it is one of means not ends. ${ }^{163}$

Finally in this section the recent practice of the ECtHR in respect of Article 46 ECHR should be noted. Article 46, as interpreted in the light of Article 1, has been held to impose upon respondent States a legal obligation to implement (under the supervision of the Council of Europe's Committee of Ministers), appropriate general or individual measures to secure any rights that the ECtHR has found to be violated in a given case. ${ }^{164}$ Unlike the IACtHR acting under Article 63(1) ACHR the ECtHR has not expressly linked its remedial findings to vindication of the right to truth, but it has for example given advice about urgent steps to be taken to address the issue of the systemic failure to investigate disappearances in the Northern Caucasus, including to establish a single, sufficiently high-level body in charge of solving disappearances in the region in addition to pursuing an effective criminal investigation. ${ }^{165}$

\section{B. Admissibility ratione temporis and Transitional Jurisprudence}

In the previous section we saw that the European system draws a sharp distinction between disappearances (giving rise to continuing violations) and killings (and other instantaneous acts). This distinction becomes even more important in relation to the ECtHR's transitional jurisprudence on the right to truth, and so they will be examined separately.

\footnotetext{
159 Brecknell (n 157) paras 68-69 (emphasis added).

160 See eg Gasyak v Turkey (App No 27872/03) ECHR 13 October 2009, amongst many others.

161 See eg Amuyeva v Russia (App No 17321/06) ECHR 25 November 2010, likewise amongst many others.

162 Al-Skeini v the United Kingdom (App No 55721/07) (2011) 53 EHRR 18, para 164.

163 Breckell (n 157), para 66; Al-Skeini (n 162) para 166.

164 See eg Aslakhanova and Others $v$ Russia (App Nos 2944/06 and 8300/07, 50184/07, 332/08, 42509/10) ECHR 18 December 2012, para 210. 


\section{Historical disappearances}

In common with the IACtHR, the ECtHR has characterized disappearances as giving rise to a continuing situation ${ }^{166}$ in respect of which procedural obligations to investigate will persist as long as the fate of the missing person is unknown, and even where death may be presumed. ${ }^{167}$ On this basis the ECtHR has established temporal jurisdiction in relation to disappearances resulting from the Turkish invasion of Cyprus in 1974, even though Turkey only accepted the right of individual petition in $1987 .{ }^{168}$ Thus in the 2009 judgment in Varnava $v$ Turkey the failure of the Turkish authorities to conduct an effective investigation into the fate of people who disappeared in life-threatening circumstances in 1974 disclosed a continuing violation of Article 2 ECHR. ${ }^{169}$ The ECtHR made this finding even though it acknowledged it may be the case that, 'both sides in [the] conflict prefer not to attempt to bring out [events within the conflict] to the light of day', and may prefer a more 'politically sensitive' approach. ${ }^{170}$ In the Varnava judgment the ECtHR also found inter alia a violation of the next of kin's Article 3 rights arising from the length of time over which they had been denied an investigation, and from 'official indifference in face of their acute anxiety to know the fate of their close family members [sic]'. ${ }^{171}$

Thus, in relation to historical disappearances there has been European jurisprudence that is functionally equivalent to that seen at the HRC and IACtHR, which in those jurisdictions was underpinned by the right to truth (expressly in relation to the right to a remedy at the IACtHR, and freedom from inhuman treatment at the HRC). The European jurisprudence developed in relation to the 1974 events in Cyprus, but has since been applied inter alia to disappearances commencing in the violent break-up of the former Yugoslavia in the 1990s, well before the Balkan States signed and ratified the ECHR. ${ }^{172}$

\section{Historical confirmed deaths and next of kin rights to humane treatment}

Whilst the European jurisprudence on next of kin rights in relation to historical disappearances is similar to that of the HRC and IACtHR the situation in respect

\footnotetext{
166 Varnava v Turkey (App No 16064/90) (2010) 50 EHRR 21, para 148; the ECtHR had already observed that disappearances have a continuing dimension in the judgment in the inter-State case of Cyprus v Turkey (n 144): see para 136. On continuing violations at the ECtHR see generally, A Van Pachtenbeke and Y Haeck, 'From De Becker to Varnava: The State of Continuing Situations in the Strasbourg Case Law' (2010) EHRLR 47.

167 Varnava (n 166) para 148.

168 ibid, para 150. In its 1996 judgment in Loizidou v Turkey (App No 15318/89) (1997) 23 EHRR 513 the ECtHR had already established Turkey could be held responsible for human rights violations in northern Cyprus, and that the Court would have temporal jurisdiction over other types of violation continuing after the critical date for Turkey.

169 Varnava (n 166) para 194. $\quad 170$ ibid, para 193. 171 ibid, para 202.

172 Skendžić and Krznarić v Croatia (App No 16212/08) ECHR 20 January 2011. Compare Skendžić and Krznarić with Palić v Bosnia and Herzegovina (App No 4704/04) ECHR 15 February 2011, where the ECtHR gained temporal jurisdiction, but declined to find a violation of the procedural limb of art 2 .
} 
of historical 'confirmed deaths' is very different, thereby preventing findings such as those in the Sankara View and Moiwana Community judgment of the HRC and IACtHR, respectively. ${ }^{173}$

The dominant European approach is clearly visible in the contrast between the ECtHR Chamber and Grand Chamber judgments in the case of Janowiec $v$ Russia. The case concerned the secret Soviet execution of nearly 22,000 Polish prisoners of war in 1940, in (amongst other places) the Katyn Forest. ${ }^{174}$ The case, which we shall return to below, was brought by family members of those who were killed; who complained inter alia that their treatment by the Russian authorities after it signed and ratified the ECHR in 1998 amounted to inhuman and degrading treatment. Citing the Sankara HRC View ${ }^{175}$ the Chamber found a violation of Article 3 ECHR, ${ }^{176}$ observing that compliance with Article 3 in cases such as this entailed that States must, 'exhibit a compassionate and respectful approach' ${ }^{177}$ — whereas the Russian authorities had, 'demonstrated a flagrant, continuous and callous disregard for [the applicants'] concerns and anxieties'. ${ }^{178}$ However, the Grand Chamber found that by the time Russia had ratified the ECHR there was no uncertainty as to the fate of the prisoners and that, "what could initially have been a "disappearance" case must be considered to be a "confirmed death" case'. ${ }^{179}$ Having made this dubious finding, the Grand Chamber then declined to find a violation of Article 3 ECHR. The Grand Chamber noted the applicants' 'profound grief and distress' but found that it did not reach, 'a dimension and character distinct from the emotional distress which may be regarded as inevitably caused to relatives of victims of a serious human rights violation'. ${ }^{180}$

\section{Historical confirmed deaths and next of kin procedural rights: the ECtHR} 'genuine connection' test emerges

In Sankara and Moiwana Community the HRC and IACtHR both also examined the next of kin's right to a remedy. As noted above, the ECtHR's approach to the Article 13 ECHR express right to a remedy is to see it as an adjunct to violations of other rights, rather than the source of extensive procedural obligations. Whilst the IACtHR and HRC have been able to (more or less explicitly) vindicate the right to truth in respect of historical killings through contemporary duties to investigate and prosecute emanating from an express right to a remedy, such an option is thus not open to the ECtHR. Instead, in respect of confirmed deaths (and accusations of historical

\footnotetext{
173 Sankara (n 74); Moiwana Community (n 131).

174 Janowiec v Russia (Chamber) (App Nos 55508/07 and 29520/09) ECHR 16 April 2012, para 16; Janowiec v Russia (GC) (n 98) para 19.

175 See in particular Janowiec v Russia (Chamber) (n 174) para 163.

176 Janowiec (Chamber) (n 174) para $167 . \quad 177$ ibid, para 163.

179 Janowiec (GC) (n 98) para 187. 
torture), it has examined the temporal scope of the procedural obligations arising from the right to life (or right to freedom from torture) itself. Here its approach is unique, and is at least potentially hugely significant for the vindication of the right to truth in transitional human rights jurisprudence.

The ECtHR, in common with the HRC and IACtHR, has accepted that it has no temporal jurisdiction over State responsibility for a life allegedly taken or lost 'instantaneously' before the crucial date. This element of the European jurisprudence runs in parallel with its approach to instantaneous acts of property confiscation before the crucial date. ${ }^{181}$ However the ECtHR has since observed that the property jurisprudence on temporal admissibility is 'of a general character' and that the 'special nature' of certain rights, including Articles 2 and 3 ECHR, should be taken into consideration. ${ }^{182}$ After a period in which, by its own admission, ${ }^{183}$ different Chambers of the ECtHR had taken varying approaches to the temporal scope of the procedural dimension of Articles 2 and 3 ECHR, in the case of Silih v Slovenia the Court set out to provide some clarity. The Silih case was not so much about the right to truth within the legacy of a totalitarian regime, but the implications for transitional jurisprudence became clear soon afterwards.

The Silih case concerned the death in hospital of the applicants' son in May 1993, after he had sought medical assistance for nausea and itching skin. Slovenia only ratified the ECHR in June 1994-over a year after the death. However, the applicants had initiated several allegedly defective civil and criminal proceedings after the crucial date. Slovenia argued that the acts or omissions by which a Convention right was allegedly infringed and the proceedings related to them were indivisible and so could not be examined separately. ${ }^{184}$ The ECtHR, however, found that the procedural obligation under Article 2 ECHR to carry out an effective investigation had evolved into a separate and 'autonomous' duty, ${ }^{185}$ capable of binding Slovenia even though the death occurred before the crucial date. ${ }^{186}$ This is functionally comparable to the IACtHR's use of Articles 8 and 25 ACHR, in which we have seen that the right to truth may be 'subsumed'. However, the ECtHR went on, the detachable procedural obligation in respect of deaths before the crucial date was 'not openended' ${ }^{187}$ At this point in the judgment, the Grand Chamber set out conditions that would need to be met. These conditions add a degree of complexity that is absent from the Inter-American and HRC jurisprudence but, at least in theory,

181 Bleĉić v Croatia (App No 59532/00) (2006) 43 EHRR 48, para 86. On the ECHR's transitional property jurisprudence see A Buyse, Post-Conflict Housing Restitution: The European Human Rights Perspective with a Case Study on Bosnia and Herzegovina (Intersentia 2008). See also eg Papamichalopoulos v Greece (App No 14556/89) (1993) 16 EHRR, concerning property de facto expropriated by the Greek military government in 1967; and Loizidou $v$ Turkey [1996] ECHR 70, concerning property rendered inaccessible by the establishment of the so-called 'Turkish Republic of Northern Cyprus'.

$\begin{array}{lll}182 \text { Silih v Slovenia (n 17) para } 147 . & 183 \text { ibid, para } 152 . & 184 \text { ibid, para } 130 . \\ 185 \text { ibid, para } 159 . & 186 \text { ibid. } & 187 \text { ibid, para } 161 .\end{array}$ 
presented a distinctive and powerful route to vindication of the right to truth in transitional human rights jurisprudence.

First, only procedural acts or omissions that took place after ratification could fall within the temporal jurisdiction of the Court. ${ }^{188}$ Second, there would have to be a 'genuine connection' between the death and the entry into force of the Convention, in the sense that 'a significant proportion' of the procedural steps required by Article 2 'will have been or ought to have been carried out after the critical date'. ${ }^{189}$ There was, however, to be a further means of establishing the 'genuine connection', with the Grand Chamber stating that,

in certain circumstances the connection could also be based on the need to ensure that the guarantees and the underlying values of the Convention are protected in a real and effective manner. ${ }^{190}$

The Court noted that all the unsuccessful criminal and civil proceedings in this case had been initiated after June 1994, and that therefore there was a 'genuine connection'. ${ }^{191}$ A violation of Article 2 in its procedural dimension was established. The ECtHR has since clarified that the Silih route to temporal admissibility is available also in respect of 'instantaneous' acts of torture prior to the crucial date. ${ }^{192}$

\section{The ECtHR 'genuine connection' test and transitional jurisprudence}

In a series of cases brought against Romania the ECtHR applied the Silih approach to temporal admissibility to gain jurisdiction over flaws in a contemporary investigation into killings carried out during and soon after the fall of the communist Ceausescu regime, in 1989. ${ }^{193}$ This was despite that the ECHR only entered into force for Romania in June 1994. In examining the procedural aspect of Articles 2 and 3 ECHR in relation to the events in Romania, the ECtHR has observed, 'the right of the numerous victims to know what had happened', ${ }^{194}$ and acknowledged 'the right of victims and

188 ibid, para $162 . \quad 189$ ibid, para $163 . \quad 190$ ibid (emphasis added).

191 It is fair to say that not all of the judges were particularly happy with the new test: see in particular the Concurring opinion of Judge Lorenzen; the Concurring opinion of Judge Zagrebelsky joined by Judges Rozakis, Cabral Barreto, Spielmann and Sajó; and the Joint dissenting opinion of Judges Bratza and Türmen.

192 See Tuna v Turkey (App No 22339/03) ECHR 19 January 2010, para 58ff; Stanimirović v Serbia (App No 26088/06) ECHR 18 October 2011, para 28.

193 Including Agache and Others $v$ Romania (App No 2712/02) ECHR 20 October 2009; Sandru and Others $v$ Romania (App No 22465/03) ECHR 8 December 2009; Association ' 21 December 1989' and Others $v$ Romania (App Nos 33810/07 and 18817/08) ECHR 24 May 2011; Catalina Filip v Romania (App No 15052/09) ECHR 21 April 2015; Melnichuk and Others v Romania (App Nos 35279/10 and 34782/10) ECHR 5 May 2015.

94 Association '21 December 1989' (n 193) para 142; Mocanu v Romania (Chamber) (App Nos 10865/09, 45886/07 and 32431/08) ECHR 13 November 2012, para 230. The Mocanu case was later referred to a Grand Chamber, which upheld and indeed expanded the findings of the Chamber but did not refer to the 'knowing the truth' in the same way: Mocanu v Romania (Grand Chamber) (App Nos 10865/09, 45886/07 and 32431/08) ECHR 17 September 2014. 
their families and heirs to know the truth about the circumstances surrounding events involving a massive violation of rights' ${ }^{195}$ In this way the ECtHR came close to vindicating the right to truth expressly, having gained temporal jurisdiction via the 'genuine connection' test. ${ }^{196}$

The ECtHR has also established temporal jurisdiction in respect of the investigation of totalitarian crimes longer ago. In the 2013 Chamber judgment in Przemyk $v$ Poland the triggering event was the killing of the applicant's son by the police in $1983,{ }^{197}$ despite Poland only recognizing the right of individual petition in 1993. ${ }^{198}$ The ECtHR noted that the lack of rigour in the criminal justice system was, 'insufficient for coming to terms with the legacy of the totalitarian past'. ${ }^{199}$ Thus whilst the judgment did not expressly mention the right to truth, it is clear that the obligations arising from the procedural limb of the right to life can play a significant role in historical accounting in respect of transitions from totalitarianism.

The Romanian cases and Przemyk raise the question of exactly how far back in time the triggering event can be when it comes to gaining temporal jurisdiction over the procedural aspect of Articles 2 and 3 ECHR. On the face of it, the 'genuine connection' and 'underlying values' tests could be a powerful tool within the ECtHR's transitional jurisprudence for encouraging new democracies' effective investigation of their totalitarian past, in such a way as to promote the right to truth and historical accounting more broadly. It would seem, however, that the ECtHR has declined to seize this opportunity. This is illustrated by the cases of Dorado and Dorado Ortiz v Spain, concerning a killing at the start of the Spanish civil war, in 1936; and the aforementioned Janowiec Grand Chamber judgment in respect of the 1940 Katyn massacre.

The admissibility decision in Dorado and Dorado Ortiz v Spain declared the application inadmissible on the basis that the complaint was rooted in an event that preceded the adoption of the ECHR itself by 14 years, and its ratification by Spain by some 43 years. ${ }^{200}$ Under these circumstances it was 'difficult' to find a 'genuine connection' for the purposes of the Silih test. ${ }^{201}$ Regrettably, the ECtHR did not discuss the 'underlying values' aspect of the Silih test.

195 Association '21 December 1989' (n 193) para 144.

196 Note that Stanimirović v Serbia (App No 26088/06) ECHR 18 October 201, the ECtHR confirmed that the principles established in Silih similarly applied to the procedural obligation, under Art 3 ECHR, to investigate 'instantaneous' instances of torture before the crucial date. Moreover by doing so the ECtHR abandoned the approach taken in earlier cases such as Burkov $v$ Russia 2001 (dec) (App No 46671/99) ECHR 30 January 2001, in which by finding a complaint about the health effects of Communist era nuclear nesting in Semey (now in Kazakhstan) inadmissible ratione temporis, the possibility of a detachable procedural obligation under art 3 upon present-day Russia to investigate under was not considered at all.

197 Przemyk v Poland (App No 22426/11) ECHR 17 September 2013.

198 ibid, para 53.

199 ibid, para 74.

200 Dorado and Dorado Ortiz v Spain (dec) (App No 30141/09) ECHR 27 March 2012, para 36.

201 ibid. Note also that the ECtHR also found that, even if the events were characterized as a disappearance, the applicants had not displayed due diligence in making their application to, 
In the Janowiec $v$ Russia judgment (just two months after Przemyk) the ECtHR Grand Chamber set out to clarify the Šilih jurisdictional criteria, and in so doing modified them somewhat: it approached the 'underlying values' test as an alternative to, rather than a component of, the 'genuine connection' test. $^{202}$ Also, in a slight change of language, the 'underlying values' test was referred to as the 'Convention values' test. ${ }^{203}$

Examining first whether there was a 'genuine connection' and then whether the 'Convention values' test was passed, the Grand Chamber still declined jurisdiction on either ground. As to the 'genuine connection' between the triggering event and the crucial date the Grand Chamber conceded that there were no 'apparent legal criteria' for imposing a time limit for establishing such a connection, yet then promptly limited it to ten years, ${ }^{204}$ and found also that it was 'impossible' to identify real investigative steps or new information after the crucial date. ${ }^{205}$ As to 'Convention values', the Grand Chamber stated that they could not be invoked in respect of events that occurred prior to the adoption of the ECHR itself. ${ }^{206}$

This reasoning and conclusion is disappointing on several levels, especially given that the Grand Chamber reversed the Chamber's finding that there had been a violation of Article 3 ECHR, as noted above. It is an unjustifiably harsh application of the ECtHR's own earlier jurisprudence; and is at odds with the practice of the IACtHR and HRC.

In terms of the harshness of the decision on its own terms, the conclusion that it was 'impossible' to find evidence of investigative steps or new information after the crucial date should be seen alongside the Grand Chamber's own finding that Russia was in breach of its Article 38 ECHR obligation to cooperate fully with the ECtHR by supplying all relevant documents to it. ${ }^{207}$ Surely some of the 'impossibility' is causally connected to Russia's failure to cooperate. Alternatively, the Partly Dissenting Opinion of Judges Ziemele, De Gaetano, Laffranque and Keller makes a convincing argument that there were identifiable procedural shortcomings after the crucial date: their approach being comparable to the HRC's 'affirmation' doctrine.

The approach to the 'Convention values' test is also harsh. First, one might point out that the ECHR did not spring out of thin air in 1950, and its 'values' may be said to spring from what its Preamble describes as a, 'common heritage of political traditions, ideals, freedom and the rule of law'. This 'common heritage' of adherence to the rule of law is, surely, an underlying 'Convention value' that must have predated the ECHR-and which the

given that the application was only introduced in June 2009 although the right of individual petition to the Court had been available in Spain since 1981.

202 Janowiec (GC) (n 98) para 144; for a detailed analysis of this case see C Heri, 'Enforced Disappearance and the European Court of Human Rights' ratione temporis Jurisdiction: A Discussion of Temporal Elements in Janowiec and Others v Russia' (2014) 12 JICJ 751.

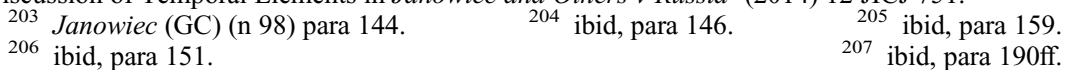


shooting of prisoners of war clearly violated. Indeed, given the horrific nature of the events, the Grand Chamber Partial Dissent of Judge Ziemele et al., quoting directly from the Partly Dissenting Chamber Opinion of Judges Spielmann, Villiger and Nußberger, advocated jurisdiction via application of the 'underlying values' test (thereby demonstrating that a substantial number of judges in total were actually in favour of jurisdiction over an alleged Article 2 procedural violation in this case). Second, it is difficult to see why it could not be a contemporary 'Convention value' that Contracting Parties investigate effectively the most notorious events in their totalitarian past (as indeed the applicants themselves had argued). ${ }^{208}$

The main problem from a comparative perspective is with the arbitrary imposition of a ten-year limit to the ECtHR's jurisdiction on the basis of the Šilih 'genuine connection' criteria. Recall that the triggering event in the Sankara HRC View took place nearly 12 years before the ICCPR and its Optional Protocol came into effect for Burkina Faso. ${ }^{209}$ In the IACtHR judgment on Preliminary Objections in Serrano Sisters, ${ }^{210}$ temporal jurisdiction was established over the failure to investigate effectively a triggering event some 13 years before El Salvador accepted the jurisdiction of the IACtHR. ${ }^{211}$ The ten-year ECtHR limit is thus clearly more strict than that seen in other human rights systems.

VI. CONCLUSION: TOWARDS A COHESIVE APPROACH TO THE ELUSIVE RIGHT TO TRUTH

One of the purposes of comparative law is to identify a richer range of solutions to common problems. ${ }^{212}$ If we accept that hiding the truth about human rights abuses of the past is a problem, then we are now in a position to identify commonalities and divergences in the way that different international human rights bodies have sought a solution. In doing so the right to truth may become a little less elusive.

In slightly different but functionally equivalent ways the HRC, IACtHR and ECtHR have upheld the substance of an individual right to truth both by recognizing that the denial of information about human rights violations can rise to the level of inhuman treatment; and also through procedural duties to investigate and prosecute. ${ }^{213}$ The fact that the ECtHR has vindicated the right to truth through the procedural obligations emanating from substantive rights,

208 ibid, para 117.

210 Serrano-Cruz Sisters (Preliminary Objections) (n 130).

209 Sankara (n 74).

211 The Serrano-Cruz Sisters case was about a disappearance, but because of a reservation by El Salvador the IACtHR was precluded from examining continuing situations and so the disappearance itself could not give rise to a violation of the ACHR. The IACtHR's examination of the next of kin's procedural rights is therefore comparable to the ECtHR jurisprudence on the duty to investigate instantaneous triggering events rather than on disappearances.

212 Zweigert and Kötz (n 22) 15.

213 See also Groome (n 5) but who perhaps underestimated the diversity of approaches between regimes identified here. 
rather than the Article 13 ECHR express right to a remedy is not, at least for this study, especially problematic: formal equivalence across the regimes would have the merit of simplicity, but it is not inherently superior. It is also important to note that although there has been less relevant jurisprudence from the African human rights system, the twin formulation of the right to truth observed here is entirely compatible with the findings of the African Commission on Human and Peoples' Rights. ${ }^{214}$ Likewise in the Norbert Zongo case the African Court has found that the failure to exercise due diligence in the investigation of a journalist's murder violated the rights of the applicants to have their case heard by competent national courts (as guaranteed by Article 7 of the African Charter on Human and Peoples' Rights), ${ }^{215}$ as well as the overarching Article 1 obligation to give effect to the rights in the African Charter. It has yet to rule on the next of kin's rights to freedom from inhuman treatment. ${ }^{216}$

Given that the right to truth in human rights law is not tied to the precise wording of particular treaties, it is particularly suited to judicial collaboration or trans-judicial dialogue. ${ }^{217}$ It might promote further judicial dialogue to be more explicit about the extent to which the right to truth simultaneously underpins both of these types of finding: until now only the IACtHR and ECtHR have expressly acknowledged that it underpins the duty to investigate and prosecute; whereas only the HRC has regularly invoked the right to truth (or 'right to know') as a constitutive element of inhuman treatment of the next of kin. Viewed as part of a comparative analysis of the right to truth, it bears repeating that the very strict ECtHR test for establishing inhuman treatment for the next of kin of victims of human rights violations other than disappearances is problematic.

Even if there continued to be some reluctance consistently to invoke the right to truth as a value within findings on the merits, it would align more with the

214 In Sudan Human Rights Organisation and Another $v$ Sudan (2009) AHRLR 153 the African Commission found that the failure to investigate effectively a range of atrocities carried out by the Janjaweed militia amounted to a breach of the duty to provide immediate remedies, and violated arts 4 and 5 of the African Charter on Human and Peoples' Rights (the right to life and the right to humane treatment). Likewise in Amnesty International and Others $v$ Sudan (2000) AHRLR 297 the Commission held that holding an individual incommunicado, and refusing to inform the family if and where the individual is being held, is inhuman treatment of both the detainee and the family concerned. In its 2015 'Principles and Guidelines on Human and Peoples' Rights while Countering Terrorism in Africa', the Commission has also expressly linked art 9 ACHPR (right to free expression) to the right to truth, and has stressed that, 'States shall not withhold information regarding gross violations of human rights or serious violations of international humanitarian law, including crimes under international law, and systematic or widespread violations of the rights to life, personal liberty, and security.'

215 African Charter on Human and Peoples' Rights (adopted 27 June 1981, entered into force 21 October 1986) 1520 UNTS 217 (African Charter).

216 But note that the African Commission has found that the incommunicado detention of journalists and political dissidents amounts to a violation of the art 18 ACHPR right to family life of not only the detainees but also their family: Article $19 v$ Eritrea (2007) AHRLR 73, para 103.

217 See Canivet (n 56). 
UN's Updated Principles on Impunity ${ }^{218}$ and Basic Principles and Guidelines on the Right to a Remedy ${ }^{219}$ to at least address it systematically within the articulation of remedial duties. We have seen that the IACtHR has already taken this step expressly when acting under Article 63(1) ACHR, but the ICCPR under Article 2(3) ICCPR and ECtHR under Article 46 ECHR have not.

On the temporal dilemma, which as noted at the outset is particularly significant for transitional human rights jurisprudence, there is agreement across regimes (including in the African system) ${ }^{220}$ that disappearances give rise to a continuing obligation to investigate and prosecute. There is also agreement in principle that, in relation to other human rights violations, sufficiently botched investigative steps after the crucial date can in certain circumstances give rise to fresh human rights violations over which the enforcement body has temporal jurisdiction. The HRC's 'affirmation doctrine' and the ECtHR's enquiry into procedural acts or omissions after the crucial date (as part of its 'genuine connection' test) have much in common. Likewise in the Norbert Zongo case the African Court also distinguished between instantaneous pre-ratification acts over which it will not have jurisdiction, and the contemporary failure to investigate-over which it will. ${ }^{221}$ It is however the IACtHR, in the Moiwana case, that has been the clearest about obligations to investigate prior human rights abuses crystallizing upon the moment the relevant human rights treaty becomes effective for a transitional State, if credible allegations are made. The approach of the IACtHR shows how the idea of the right to truth can underpin a bold approach to adjudicating on a human rights court's own temporal jurisdiction, in such a way as to impose a contemporary duty to investigate historical human rights violations.

Again though, from a comparative perspective, the approach of the ECtHR to the temporal dilemma is stricter than the other human rights enforcement bodies due to the ten-year limit imposed in the Janowiec case on the establishment of a 'genuine connection'. This would not be quite such an issue if the ECtHR's 'underlying' or 'Convention values' alternative route to temporal jurisdiction was applied with the effect of gaining jurisdiction to at least the same extent as other enforcement bodies. However, thus far no application whatsoever has passed this test. This is regrettable because as noted in the Introduction there seems to be an emerging consensus, in both scholarship and comparative human rights jurisprudence, that historical justice plays an

218 UNCHR, 'Updated Set of Principles for the Protection and Promotion of Human Rights through Action to Combat Impunity' (n 24).

219 Basic Principles and Guidelines on the Right to a Remedy (n 25).

220 Indeed the African Commission has asserted temporal jurisdiction over continuing violations rooted in disappearances that occurred well before the African Charter was even adopted: JE Zitha \& PJL Zitha v Mozambique (Comm No 361/08) ACHPR 23 February to 3 March 2011), (although note that the communication in this case was ruled inadmissible on other grounds).

221 Beneficiaries of Norbert Zongo v Burkina Faso (App No 013/2011) ACtHPR 28 March 2014. 
important part in the process of transition-whether or not it is expressly characterized as vindication of the right to truth. In fact, the ECtHR's 'underlying values' test could have led the way in promoting internationally the notion that present-day denial or obstruction of the quest for truth about the gravest pre-ratification human rights abuses may amount, in itself, to a contemporary human rights violation. Such an approach does not apply each human rights treaty retroactively, nor does it convert every historical human rights abuse into a 'continuing violation', but it establishes exceptional circumstances in which denying the right to truth about historical human rights abuses is constitutive of a fresh violation within the temporal jurisdiction of the relevant enforcement body. This would support victims' rights, and the ethos of the Basic Principles and Guidelines, ${ }^{222}$ and would promote the notion that a human rights-respectful State is one that takes its history seriously. It is also entirely compatible with the recognition that human rights violations amounting to serious international crimes are not subject to statutes of limitation..$^{223}$

Importantly though, whilst an 'underlying values' test might seem farreaching, it is bounded in at least two ways. First, if the duty to investigate also leads to prosecution, then any ensuing trial will have to conform to human rights standards including the right to a fair hearing and protection from retroactivity. Second, as the ECtHR (perhaps more so than the other bodies) has already recognized, in historical cases and conflict cases (or both), the duty to investigate is affected by countervailing factors such as the passage of time and the inherent difficulty of investigating under conditions of armed conflict. For example in the Palic judgment, which concerned a preratification death and disappearance during the conflict in the Former Yugoslavia, the ECtHR observed that,

the obligations under Article 2 must be interpreted in a way which does not impose an impossible or disproportionate burden on the authorities ... The Court takes into account the complex situation in Bosnia and Herzegovina, notably in the first ten years following the war. In such a post-conflict situation, what amounts to an impossible and/or disproportionate burden must be measured by the very particular facts and context. ${ }^{224}$

This might appear to be a form of 'transitional relativism', where human rights standards are applied relative to the transitional context $\mathrm{t}^{225}$ - but it is both pragmatic and proportionate, and would prevent an extended jurisdiction to vindicate the right to truth from being limitless. It does mean that there may

\footnotetext{
222 Basic Principles and Guidelines on the Right to a Remedy (n 25).

223 See eg Convention on the Non-Applicability of Statutory Limitations to War Crimes and Crimes Against Humanity (adopted 26 November 1968, entered into force 11 November 1970) 754 UNTS 73.

${ }_{224}$ Palić v Bosnia and Herzegovina (App No 4704/04) ECHR 15 February 2011.

225 Sweeney (n 33) 3.
} 
be circumstances where a State might be in compliance with its human rights obligations even where, due to significant countervailing factors, it has not been able to complete its investigations. However, the approach suggested here at least promotes the expectation of the right to truth being vindicated, and promotes scrutiny of States' actions in this regard.

In the Partly Dissenting Opinion of ECtHR Judge Wojtyczek in the case of Mocanu, concern was expressed that the tests established in the Šilih judgment were not clear, and that the Janowiec Grand Chamber judgment had done little to clarify them. Judge Wojtyczek, who had also dissented in Janowiec, argued that this lack of clarity could lead to 'excessive hopes' from applicants. The 'fuzziness of the law' he continued, 'may lead to the erosion of the legitimacy of the entire system of human-rights protection in Europe'. On the contrary, it may be submitted that dashing the hopes of the victims of the most serious historical human rights abuses, and their next of kin, is at least as injurious to the legitimacy and esteem of human rights law. Faced with growing hostility to international human rights courts from even fairly stable democracies, the greater threat to the protection of human rights is that transitional democracies may use such hostility to attempt to legitimize their own rights-restrictive practices. Promoting the right to truth in transitional human rights jurisprudence through an 'underlying values' approach can play an important role in preventing backsliding, and may preserve, rather than threaten, the protection of human rights. 